\title{
Chemical ozone loss and ozone mini-hole event during the Arctic winter 2010/2011 as observed by SCIAMACHY and GOME-2
}

\author{
R. Hommel ${ }^{1}$, K.-U. Eichmann ${ }^{1}$, J. Aschmann ${ }^{1}$, K. Bramstedt ${ }^{1}$, M. Weber ${ }^{1}$, C. von Savigny ${ }^{1,{ }^{*}}$, A. Richter ${ }^{1}$, \\ A. Rozanov ${ }^{1}$, F. Wittrock ${ }^{1}$, F. Khosrawi ${ }^{2}$, R. Bauer ${ }^{1, * *}$, and J. P. Burrows ${ }^{1}$ \\ ${ }^{1}$ Institute of Environmental Physics (IUP), University of Bremen, Bremen, Germany \\ ${ }^{2}$ Department of Meteorology, Stockholm University, Stockholm, Sweden \\ *now at: Institute of Physics, Ernst Moritz Arndt University of Greifswald, Greifswald, Germany \\ ** now at: Department of Physics, University of Toronto, Toronto, Canada
}

Correspondence to: R. Hommel (rene.hommel@iup.physik.uni-bremen.de)

Received: 1 May 2013 - Published in Atmos. Chem. Phys. Discuss.: 20 June 2013

Revised: 14 February 2014 - Accepted: 19 February 2014 - Published: 2 April 2014

\begin{abstract}
Record breaking loss of ozone $\left(\mathrm{O}_{3}\right)$ in the Arctic stratosphere has been reported in winter-spring 2010/2011. We examine in detail the composition and transformations occurring in the Arctic polar vortex using total column and vertical profile data products for $\mathrm{O}_{3}$, bromine oxide $(\mathrm{BrO})$, nitrogen dioxide $\left(\mathrm{NO}_{2}\right)$, chlorine dioxide $(\mathrm{OClO})$, and polar stratospheric clouds (PSC) retrieved from measurements made by SCIAMACHY (Scanning Imaging Absorption SpectroMeter for Atmospheric CHartography) onboard Envisat (Environmental Satellite), as well as total column ozone amount, retrieved from the measurements of GOME-2 (Global Ozone Monitoring Experiment) on MetOp-A (Meteorological Experimental Satellite). Similarly we use the retrieved data from DOAS (Differential Optical Absorption Spectroscopy) measurements made in $\mathrm{Ny}-$ Ålesund $\left(78.55^{\circ} \mathrm{N}, 11.55^{\circ} \mathrm{E}\right)$. A chemical transport model (CTM) has been used to relate and compare Arctic winterspring conditions in 2011 with those in the previous year. In late winter-spring 2010/2011 the chemical ozone loss in the polar vortex derived from SCIAMACHY observations confirms findings reported elsewhere. More than $70 \%$ of $\mathrm{O}_{3}$ was depleted by halogen catalytic cycles between the 425 and $525 \mathrm{~K}$ isentropic surfaces, i.e. in the altitude range $\sim 16$ $20 \mathrm{~km}$. In contrast, during the same period in the previous winter 2009/2010, a typical warm Arctic winter, only slightly more than $20 \%$ depletion occurred below $20 \mathrm{~km}$, while $40 \%$ of $\mathrm{O}_{3}$ was removed above the $575 \mathrm{~K}$ isentrope $(\sim 23 \mathrm{~km})$. This loss above $575 \mathrm{~K}$ is explained by the catalytic destruction by $\mathrm{NO}_{\mathrm{x}}$ descending from the mesosphere. In both Arctic
\end{abstract}

winters 2009/2010 and 2010/2011, calculated $\mathrm{O}_{3}$ losses from the CTM are in good agreement to our observations and other model studies. The mid-winter 2011 conditions, prior to the catalytic cycles being fully effective, are also investigated. Surprisingly, a significant loss of $\mathrm{O}_{3}$ around $60 \%$, previously not discussed in detail, is observed in mid-January 2011 below $500 \mathrm{~K}(\sim 19 \mathrm{~km})$ and sustained for approximately 1 week. The low $\mathrm{O}_{3}$ region had an exceptionally large spatial extent. The situation was caused by two independently evolving tropopause elevations over the Asian continent. Induced adiabatic cooling of the stratosphere favoured the formation of PSC, increased the amount of active chlorine for a short time, and potentially contributed to higher polar ozone loss later in spring.

\section{Introduction}

Predicting the future levels of ozone $\left(\mathrm{O}_{3}\right)$ above the Arctic and its loss during winter-spring is intrinsically challenging. The history of the observations of stratospheric ozone at high latitudes has repeatedly resulted in unexpected behaviour usually explained by our limited knowledge of the dynamics and chemistry. Accurate scientific assessments of the evolution of polar ozone in a changing climate are required by the parties to the United Nation's Vienna Convention on ozone depleting substances and its Montreal Protocol/amendments. This study addresses measurements of trace gases and polar stratospheric clouds of relevance to this requirement. 
In contrast to the Southern Hemisphere, the northern polar vortex is much less stable and a large interannual variability of stratospheric ozone at mid- and high-latitudes occurs. This variability is closely related to year-to-year changes in the activity of planetary waves (Fusco and Salby, 1999; Weber et al., 2011), modulating the intensity, temporal evolution and stability of the Arctic polar vortex (e.g. Hartmann et al., 2000; Dhomse et al., 2006; Mitchell et al., 2011, and references therein). By determining the vortex temperature, this in turn modulates the effectiveness of the catalytic cycles removing stratospheric ozone in late winter and spring after polar sunrise via the formation of polar stratospheric clouds. As a result heterogeneous reactions and equilibria, which take place on aerosol and PSC (polar stratospheric cloud), convert the relatively photo-stable species such as hydrogen chloride $(\mathrm{HCl})$, chlorine nitrate $(\mathrm{ClONO} 2)$, bromine nitrate $\left(\mathrm{BrONO}_{2}\right)$ and hypobromous acid $(\mathrm{HOBr})$ into the photo-labile species molecular chlorine $\left(\mathrm{Cl}_{2}\right)$, bromine chloride $(\mathrm{BrCl})$, bromine $\left(\mathrm{Br}_{2}\right)$ and related halogen temporary reservoirs. The rate of removal of ozone is thus strongly dependent on particular dynamical conditions in a given winter and spring (WMO, 2011, and references therein). In winterspring 2011, anomalously large ozone loss in the Arctic stratospheric polar vortex was reported (e.g. Hurwitz et al., 2011; Manney et al., 2011; Sinnhuber et al., 2011; Balis et al., 2011; Arnone et al., 2012; Adams et al., 2012; Kuttippurath et al., 2012; Pommereau et al., 2013). In March 2010, however, when the Arctic stratosphere was also extensively denitrified and large chlorine activation was observed (Manney et al., 2011; Khosrawi et al., 2011; von Hobe et al., 2013), polar ozone was unusually high (Kuttippurath et al., 2010; Steinbrecht et al., 2011; Wohltmann et al., 2013).

In spite of the first indications of stratospheric ozone recovery, as a result of the measures enacted by the Montreal Protocol (see WMO, 2011, and references therein) and inferred from the studies of Mäder et al. (2010) and Salby et al. (2011), an ongoing potential for further, yet unexpected, dramatical polar ozone loss exists (e.g. Rex et al., 2004). It is therefore of value to examine the causes of Arctic variability and their impact on polar ozone and its depletion, in order to improve our understanding of the chemical and dynamical control of stratospheric ozone in a changing climate.

In this manuscript we investigate how the 2011 ozone loss evolved in the Arctic polar vortex by reporting correlative observations of ozone and related species $\left(\mathrm{BrO}, \mathrm{NO}_{2}\right.$, $\mathrm{OClO}$ ), including $\mathrm{PSC}$, and probe our understanding of the vortex behaviour with a chemistry transport model. One focus is the investigation of vertically resolved data and we compare the situation with 2010, when the temperatures in the Arctic vortex were much higher and ozone was only moderately destroyed (e.g. Kuttippurath et al., 2010; Dörnbrack et al., 2012; Wohltmann et al., 2013). We use spaceborne observations from the SCIAMACHY (Scanning Imaging Absorption SpectroMeter for Atmospheric CHartography) instrument in the limb, solar-occultation and nadir- viewing geometries. Additionally, we show observations from the nadir sounders GOME (Global Ozone Monitoring Experiment) and GOME-2, and ground-based DOAS (Differential Optical Absorption Spectroscopy) measurements above the NDACC's (Network for the Detection of Atmospheric Composition Change) Koldewey station, which is part of the French-German Arctic Research Base on Spitsbergen/Svalbard, Kongsfjorden, Ny-Ålesund $\left(78.55^{\circ} \mathrm{N}\right.$, $\left.11.55^{\circ} \mathrm{E}\right)$.

For the first time, we show vertically resolved and vortex-averaged $\mathrm{BrO}$ abundances obtained from the SCIAMACHY limb and solar-occultation observations, simultaneously measured with $\mathrm{NO}_{2}$ and $\mathrm{O}_{3}$, to further evaluate the role of $\mathrm{BrO}$ in the catalytic cycles destroying Arctic ozone. Due to remaining uncertainties in the stratospheric bromine budget (WMO, 2011), the relative contribution of reactive bromine to the Arctic ozone loss is still not fully understood (e.g. Frieler et al., 2006). Depending on the specific dynamic situation of the Arctic polar vortex during winter and spring, the efficiency of the $\mathrm{ClO} / \mathrm{BrO}$ cycle for ozone loss may dominate below the altitudes where nitrogen oxides $\left(\mathrm{NO}_{\mathrm{x}}=\mathrm{NO}+\mathrm{NO}_{2}\right)$ catalytic cycles destroy most of the ozone (e.g. Salawitch et al., 2005; Kuttippurath et al., 2010). Our SCIAMACHY observations clearly demonstrate that the $\mathrm{BrO}$ radical is highly abundant over a broad altitude region inside the polar vortex throughout the winter and spring in 2010 and 2011, until increasing stratospheric temperatures shift the chemical equilibrium towards the reservoir species. However, the bromine radical is much longer present in the polar stratosphere than its chlorine counterpart, with the potential to continue ozone depletion in persistent vortex remnants when PSC are no longer present.

The paper is structured as follows: Sect. 2 describes the methods and data sources used in the analysis. Section 3 documents the interannual variability of total ozone over the Arctic in the context of measurements since 1995/1996. Additional, differences in the distributions of data-set specific stratospheric partial ozone columns are discussed. Section 4 explores the time-dependent behaviour of the vortexaveraged time series from SCIAMACHY limb and solaroccultation measurements as well as corresponding model simulations. In Sect. 5, the SCIAMACHY limb-scatter PSC record is analysed. This is then followed in Sect. 6 by an inspection of the $\mathrm{NO}_{2}$ and $\mathrm{OClO}$ records from the SCIAMACHY nadir observations and, exemplarily for specific years, from ground-based DOAS measurements in NyÅlesund $\left(78.55^{\circ} \mathrm{N}, 11.55^{\circ} \mathrm{E}\right)$. Section 7 provides further discussions on a previously unreported period in mid-winter 2011 when ozone in the Arctic stratosphere was also unusually low prior to its catalytic chemical decomposition in spring. Section 8 summarises our results and interpretation of these two unique winters in 2010 and 2011 (the abbreviations are defined in Table A1 of the Appendix). 


\section{Methods}

We use data products retrieved from SCIAMACHY on-board ESA's Envisat satellite (Burrows et al., 1995; Bovensmann et al., 1999) and from the GOME instrument on-board ESA's second European Remote Sensing satellite (ERS-2; Burrows et al., 1999) and its operational successor GOME-2 onboard EUMETSAT's Meteorological Operational satellite (MetOp-A; Callies et al., 2000).

For almost a decade (2002-2012) SCIAMACHY provided a unique record of the upwelling UV and visible radiation at the top of the atmosphere from different viewing geometries: nadir, providing trace gas columns, aerosol and cloud properties, and limb/solar and lunar occultation, providing trace gas and aerosol profiles and PSC information. Its limb and occultation measurements yield profiles of atmospheric constituents from the troposphere to the thermosphere. While solar-occultation measurements are restricted to northern latitudes between 49 and $69^{\circ} \mathrm{N}$, limb and nadir measurements achieve global coverage every 6 days.

GOME operated from 1995 to 2011 and GOME-2 since 2007. They have been making global measurements in nadir viewing geometry of the upwelling electromagnetic radiation between 233 and $793 \mathrm{~nm}$. From GOME, SCIAMACHY, and GOME-2 nadir observations trace gas total column amounts of ozone and other trace species can be obtained covering nearly 20 years.

\subsection{SCIAMACHY limb trace gas profiles}

Vertical profiles of atmospheric species are retrieved from limb-scatter measurements performed by the SCIAMACHY instrument on Envisat (Burrows et al., 1995; Bovensmann et al., 1999). The level 2 data products retrievals used in this investigation (version 2.5) have been developed and processed at the Institute of the Environmental Physics (IUP) of the University of Bremen (IUP Bremen retrieval) using the level 1 (version 7.03/04) data products provided by ESA. For this study several spectral windows in the UV (ultraviolet) or visible spectral ranges have been used.

The vertical ozone profile retrieval uses an optimal estimation approach employing the radiance profiles measured at selected wavelengths in the UV Hartley bands of $\mathrm{O}_{3}$ (267$305 \mathrm{~nm}$; Rohen et al., 2008) and the visible $\mathrm{O}_{3}$ Chappuis band (Sonkaew et al., 2009). The $\mathrm{NO}_{2}$ and $\mathrm{BrO}$ vertical profiles are retrieved using their differential absorption structure in the spectral ranges $420-470 \mathrm{~nm}$ and $338-356.2 \mathrm{~nm}$, respectively.

All these retrievals use an upper-atmosphere reference tangent height to normalise the limb radiance at a given tangent height in order to reduce the influence of the solar Fraunhofer lines, any errors in instrument radiometric calibration and radiation scattered in the lower troposphere or reflected from the underlying surface. The position of the reference tangent heights is optimised individually for each species and in the case of ozone with respect to the different spectral intervals used. Both $\mathrm{O}_{3}$ and $\mathrm{BrO}$ retrievals use variants on the optimal estimation-type technique (Rodgers, 2000) having an additional smoothing constraint (first order Tikhonov term), while the $\mathrm{NO}_{2}$ retrieval employs the information operator approach (see Kozlov, 1983; Hoogen et al., 1999; Doicu et al., 2007, and references therein). The pressure and temperature information used in the forward radiative transfer model is provided by the operational analysis model of the European Centre for Medium-Range Weather Forecasts (ECMWF). More detailed explanations of the retrieval algorithms and validation results for different species are reported elsewhere: e.g. for the $\mathrm{NO}_{2}$ retrieval algorithm in Rozanov et al. (2005), for the $\mathrm{O}_{3}$ algorithm in Sonkaew et al. (2009), $\mathrm{O}_{3}$ profile validation results are presented in Mieruch et al. (2012), BrO profile validation is reported by Rozanov et al. (2011a, b), and for $\mathrm{NO}_{2}$ profile validation see Bauer et al. (2012).

\subsection{SCIAMACHY solar occultation}

SCIAMACHY performs a solar-occultation measurement once per orbit. The sun-synchronous polar orbit of Envisat provides seasonally dependent occultations at mid-latitudes. These occur between 49 and $69^{\circ} \mathrm{N}$ in the Northern Hemisphere. Vertical profiles of $\mathrm{O}_{3}, \mathrm{NO}_{2}$, and $\mathrm{BrO}$ are retrieved by applying an optimal estimation approach including a smoothing constraint, similar to that used for $\mathrm{O}_{3}$ and $\mathrm{BrO}$ profiles retrieved from the limb measurements. The knowledge of the tangent height for the solar-occultation measurements has been optimised using the scans over the solar disk (Bramstedt et al., 2012). In this case $\mathrm{O}_{3}$ is retrieved from the Chappuis bands between 524.3 and $590.7 \mathrm{~nm}$. The $\mathrm{O}_{3}$ profile is then used in the retrieval of $\mathrm{NO}_{2}$ from the spectral window 424.1$453.3 \mathrm{~nm}$. Previous versions of these products are described in Meyer et al. (2005) and Bramstedt et al. (2007). The vertical profile of $\mathrm{BrO}$ is retrieved from the radiance and irradiance measurements in the spectral window $338.0-356.2 \mathrm{~nm}$ (using the knowledge of the previously retrieved $\mathrm{O}_{3}$ and $\mathrm{NO}_{2}$ profiles). This product is evaluated for the first time in this manuscript. Pressure and temperature information at a given tangent height is based on the ECMWF data also used in the limb retrievals. The solar-occultation retrievals are produced using retrieval algorithms developed at IUP Bremen.

\subsection{SCIAMACHY $\mathrm{OClO}$ and $\mathrm{NO}_{2}$ from nadir measurements}

SCIAMACHY nadir observations have been analysed for $\mathrm{OClO}$ and $\mathrm{NO}_{2}$ slant columns retrieved by DOAS (see Platt, 1994) applied to the measurements of the upwelling radiation from space (see Burrows et al., 2011, and references therein). The analysis performed here closely follows the approach described in Richter et al. (2005) applied to GOME data. 
The OClO molecule, which undergoes rapid photolysis during daytime, achieves its largest concentrations at night and thus is best measured during twilight in nadir sounding. In addition, the $\mathrm{OClO}$ amount changes rapidly along the path of electromagnetic radiation through the atmosphere and as a function of the solar zenith angle (SZA). These changes can be accounted for by simulations using radiative transfer models (Hendrick et al., 2006; Oetjen et al., 2011, and references therein). However, for the assessment of change, an optimal approach to evaluate changes in $\mathrm{OClO}$ measurements is to compare the data at a solar zenith angle of $90^{\circ}$. This avoids any error in the conversion of slant to vertical columns (Wagner et al., 2002; Richter et al., 2005) and the relative changes between years. For a quantitative comparison with models, the radiative transfer effects need to be accounted for.

At large SZA, the intensity of electromagnetic radiation leaving the top of the atmosphere is small and individual measurements of OClO, retrieved from SCIAMACHY observations, have a relatively low signal to noise and thus relatively large retrieval errors. By averaging over the measurements made at SZAs between 89 and $91^{\circ}$ the error and resultant scatter is reduced. This approach has been validated by comparison with ground-based zenith-sky observations, where very good agreement was obtained (Oetjen et al., 2011).

$\mathrm{NO}_{2}$ is also photolysed by ultraviolet radiation but the changes along the path of ultraviolet radiation are smaller than those for $\mathrm{OClO}$ and vertical columns can be determined using appropriate air mass factors. However, to be consistent with the $\mathrm{OClO}$ observations, $\mathrm{NO}_{2}$ columns are also analysed around a SZA of $90^{\circ}$. This approach has the additional advantage of a much reduced sensitivity to the lower atmosphere, minimising any potential impact of tropospheric pollution in the Arctic.

\subsection{SCIAMACHY PSC detection description}

SCIAMACHY provides profile measurements of limbscattered solar radiation. From the profiles at 750 and $1090 \mathrm{~nm}$ we construct a colour index, which is used in combination with a defined threshold to detect PSC. As shown in von Savigny et al. (2005a) the retrievals are robust. For almost all of the detections of PSC the ECMWF temperature at the location and altitude of the detected PSC is consistent with the known PSC temperature formation threshold of about 195-198 K. The current PSC detection scheme does not allow one to distinguish between different PSC types.

In von Savigny et al. (2005a) only PSC observations in the Southern Hemisphere were analysed, while in this study we show results obtained from SCIAMACHY measurements in the Northern Hemisphere for the first time. In contrast to the southern hemispheric observations with scattering angles of up to $160^{\circ}$, the northern hemispheric SCIAMACHY limbscatter observations - particularly at high latitudes - are associated with relatively small scattering angles as low as about $25^{\circ}$. This difference in scattering angles required a minor optimisation of the PSC detection threshold applied to the vertical gradients of the colour-index ratio. For the analyses presented here a threshold value of $\theta=1.45$ is used. More detailed information on the PSC detection method can be found in von Savigny et al. (2005a).

\subsection{Ground based measurements}

Ground-based zenith sky observations made at Ny-Ålesund $\left(78.55^{\circ} \mathrm{N}, 11.55^{\circ} \mathrm{E}\right)$ have been used to retrieve $\mathrm{OClO}$ and $\mathrm{NO}_{2}$ slant columns using the DOAS (Platt, 1994) method. The spectral window and related settings are similar to those used with SCIAMACHY radiances for the retrieval of tracegas slant columns. Here, as reference spectrum, a measurement at a small solar zenith angle is used: the SZA being typically about $80^{\circ}$. For more details see Oetjen et al. (2011).

\subsection{Long-term total column ozone data set}

A consistent, consolidated and merged $\mathrm{O}_{3}$ total column data set, retrieved from the nadir measurements made by GOME, SCIAMACHY (Bracher et al., 2005) and GOME-2 (Coldewey-Egbers et al., 2005; Weber et al., 2005), called in short the GSG data set, has been compiled at IUP (Weber et al., 2007). In the GSG data set the SCIAMACHY (2002-2012) and the well-validated GOME data record (1995-2011) have been used to normalise the data sets by a mean scaling factor (GOME-2 and SCIAMACHY) and trend (SCIAMACHY only) in the monthly mean zonal mean ratios. Using the selection criterion of maximum global sampling, the GSG data set is then composed of GOME from 1995 to June 2003, SCIAMACHY from 2003 to 2006 and GOME-2 after 2006. This data set has already been used in other related studies (Kiesewetter et al., 2010a, b). Data are available from http://www.iup.uni-bremen.de/gome/wfdoas. Another long-term data set is the merged SBUV/TOMS/OMI $\mathrm{O}_{3}$ data set (Mod V8; http://acdb-ext.gsfc.nasa.gov/Data services/merged) that extends from 1978 to present (Stolarski and Frith, 2006). It agrees within $2 \%$ with the GSG data set when comparing monthly mean zonal means.

\subsection{Chemical ozone loss calculation}

The chemical ozone loss has been calculated using ozone profiles retrieved in the polar vortex. This approach has been explained in more detail by Eichmann et al. (2002). The method has been adapted to SCIAMACHY ozone limb profiles using meteorological data from the UK Met Office (UKMO) for the determination of the vortex edge and the calculation of diabatic descent rates (Sonkaew et al., 2013). Retrieved SCIAMACHY ozone number density profiles were converted to volume mixing ratios and interpolated to isentropic levels between 425 and $600 \mathrm{~K}$ using UKMO meteorological data. The potential vorticity is used to select the SCIAMACHY measurements made inside the vortex. 
According to Nash et al. (1996), the polar vortex boundary is determined by a modified potential vorticity value of $38 \mathrm{PVU}$ $\left(1 \mathrm{PVU}=1 \times 10^{-6} \mathrm{~K} \mathrm{~m}^{2} \mathrm{~kg}^{-1} \mathrm{~s}^{-1}\right)$, which was also used in the study of Sonkaew et al. (2013), where polar ozone losses during the first 7 years of SCIAMACHY limb observations were examined. All SCIAMACHY limb profiles with a PV above that value are averaged to give a daily vortex mean. Additionally, heating rates calculated with the MIDRAD radiative transfer model (Shine, 1987) are used to infer the diabatic descent rate for each measurement. These are also averaged to give a vortex-mean diabatic descent. From the vortex-mean diabatic descent, the dynamical ozone supply to the vortex-mean ozone at a given isentropic level is calculated. At the end of the winter-spring the sum of the "measured" ozone loss (observed ozone difference between starting date and end date) and the accumulated dynamical supply yields the net chemical ozone loss at a given isentrope. Measurements of optical spectrometers such as SCIAMACHY, GOME, or GOME-2 are made only in sunlit parts of the vortex. The coverage of the vortex at the beginning of the year after the sun comes back to the polar regions is thus somewhat sparse. Closer to the end of the vortex lifetime in early spring, parts of the vortex are observed more than once during 1 day and the vortex can also be probed at different local times. While the local time of the SCIAMACHY measurements inside the Arctic polar vortex is close to 11:00 LT (local time) in January, it changes during winter and spring and can reach to around 19:00 LT at the beginning of April for measurements near the pole. This is not considered to be a limitation for the determination of the ozone loss, as the diurnal variation of $\mathrm{O}_{3}$ within the vortex at a given potential temperature is negligible. This is not the case for the interpretation of the $\mathrm{NO}_{2}$ and $\mathrm{BrO}$ within the vortex as these species have significant diurnal variations.

In addition to the vortex boundary criteria to select the measured profiles for vortex averaging, we consider only measurements made south of $80^{\circ} \mathrm{N}$. This is done in order to retain accuracy with respective model estimates, because the local time of SCIAMACHY overpass in the model is a grid cell average that is becoming unprecise near the poles. This additional selection ensures that calculated vortex averages are compared under approximately similar conditions.

Unlike $\mathrm{O}_{3}, \mathrm{BrO}$ and $\mathrm{NO}_{2}$ fields have in comparison relatively strong diurnal variations or dependence on SZA, in sunlit polar vortex conditions. SCIAMACHY measurements are moving closer to the pole during the course of the winterspring period because of the rising sun. Thus springtime vortex averages may be compiled from different local times, as for the higher latitudes there are $2-3$ orbits crossing the same geolocation. Even if the overall number of profiles considered in the averages steadily increases with time, making the vortex averages more representative, the uncertainty of the inferred vortex-average $\mathrm{BrO}$ and $\mathrm{NO}_{2}$ time series increase by $5-15 \%$ when the vortex weakens during polar spring.

\subsection{Chemistry transport model}

For this study, an isentropic three-dimensional CTM with 29 levels between 330 and $2700 \mathrm{~K}$ (about $10-55 \mathrm{~km}$ ) and a horizontal resolution of $2.5^{\circ} \times 3.75^{\circ}$ in latitude and longitude has been used (Sinnhuber et al., 2003; Aschmann et al., 2009,2011 ). The model is driven by horizontal wind fields and temperature, provided by the ERA-Interim reanalysis of the ECMWF. The chemistry scheme comprises 59 tracers and about 180 gas-phase, heterogeneous and photochemical reactions and is an extended version of the SLIMCAT model described by Chipperfield (1999). Updates and improvements of the model set-up have been reported in Sinnhuber et al. (2003) and Winkler et al. (2008). Reaction rates and absorption cross sections are taken from the Jet Propulsion Laboratory recommendations (Sander et al., 2006, and updates). An equilibrium treatment of polar stratospheric cloud formation, including liquid aerosols, solid nitric acid trihydrate and ice particles is implemented within the model.

The model run used in this study is a continuation of the original 21 year integration presented in Aschmann et al. (2011). However, unlike the previous runs the vertical transport is derived from interactively calculated diabatic heating rates using the MIDRAD scheme (Shine, 1987). Identical to Aschmann et al. (2011), the model contains an additional 5 pptv of very short-lived bromine source gases. The model integrations started in June 2009/2010, running until April of the next year.

To estimate ozone loss, we added an additional quasipassive ozone tracer, which is initialised with the standard ozone tracer. This is not completely passive but uses an adapted version of the linearised chemistry scheme LINOZ (McLinden et al., 2000; Kiesewetter et al., 2010b). This is to capture the impact of the large-scale ozone photochemistry independently from the main chemistry scheme. As the linearised scheme does not contain any parametrisation for heterogeneous chemistry, the difference between the quasipassive and the standard ozone tracer reveals the desired information about the chemical loss caused by heterogeneous multiphase processes. Similarly to the approach used to infer vortex-averaged ozone loss from SCIAMACHY limb measurements, for the calculation of model vortex averages only those grid cells are taken into account where the modified potential vorticity exceeds $38 \mathrm{PVU}$ at latitudes south of $80^{\circ} \mathrm{N}$, and where the solar zenith angle is between 75 and $88^{\circ}$ on local time of SCIAMACHY overpass.

As the model does not explicitly cover the domain below $10 \mathrm{~km}$, we use a static monthly mean zonal mean climatology (Fortuin and Kelder, 1998) to calculate the tropospheric contribution to total column ozone. 


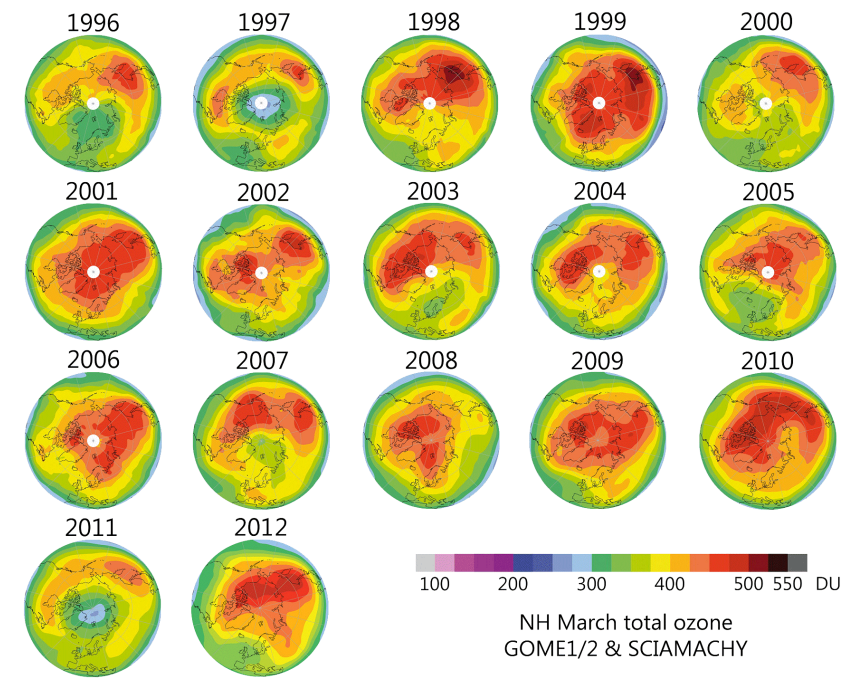

Fig. 1. Polar stereographic maps of mean Arctic total ozone in March as obtained from the GSG data set, containing observations from GOME (1996-2003), SCIAMACHY (2003-2006) and GOME-2 (2007-2012). The Arctic spring 2010 is a year with unusually high ozone levels representative of a warm Arctic winterspring season, while 2011 low ozone levels are the result from a cold Arctic winter-spring season with substantial polar ozone loss.

\section{Winter-spring 2011 Arctic total ozone in the context of measurements since 1995}

\subsection{Interannual variability}

A compilation of total ozone observations from GOME (1995-2002), SCIAMACHY (2003-2006) and GOME-2 (2007-2012) over the Arctic shows that ozone patterns in March 2011 are similar to those in 1997 (Fig. 1). This can also be seen from the daily time series of polar cap ozone (i.e. area weighted and averaged over latitudes $\geq 50^{\circ} \mathrm{N}$; Fig. 2a, b), which closely follow each other in these 2 years. Polar cap mean ozone (Fig. 2a) was at a record low by day 80 (end of March) in 1997 and 2011. Minimum polar ozone (Fig. 2b) was at a record low (close to 220 DU) in March 2011 and remained unusually low until early April. Throughout March 2011 it was the lowest in the 15 year data record of the GSG data set.

The variability in Arctic ozone evident from the compact relationship between the extra-tropical September-to-March mean eddy heat flux, a measure of wave forcing of the winter residual circulation, and spring-to-fall polar cap ozone ratio, is shown in Fig. 3 (update from Weber et al., 2011). This figure shows data from both hemispheres. Triangles are used for the Southern Hemisphere (SH), circles for the Northern Hemisphere (NH). A spring-to-fall ratio larger than one indicates that ozone transport outweighs polar ozone loss (typically in the $\mathrm{NH}$ ) and smaller than one that polar ozone loss dominates (typically in the $\mathrm{SH}$ ). Planetary wave activity be-

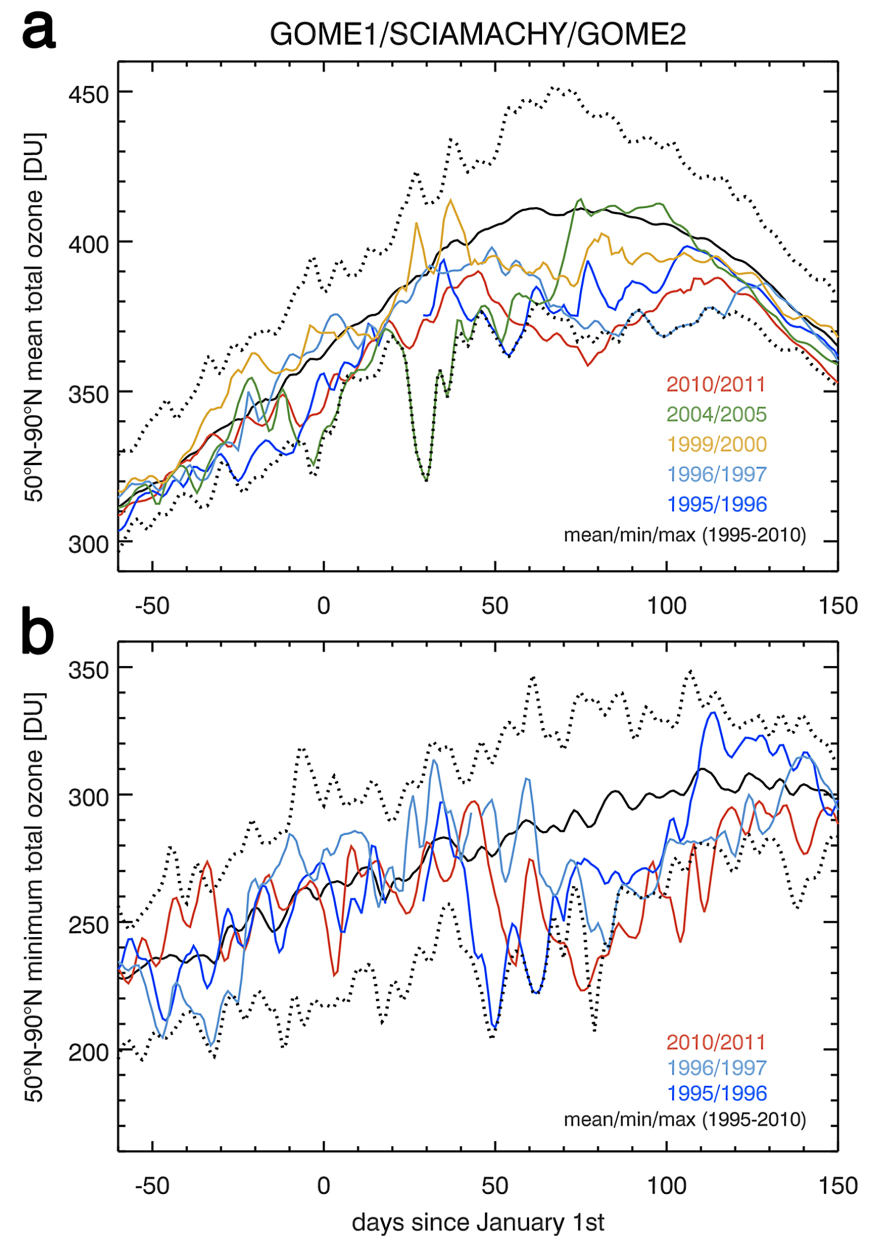

Fig. 2. Evolution of Arctic total ozone in the GSG data set for various cold winters with severe ozone losses since 1995. (a) area weighted mean and (b) the minimum total ozone as obtained from the GSG data set north of $50^{\circ} \mathrm{N}$. Coloured lines show time-series of individual Arctic winters as indicated. The solid black line is the mean of all years in the 16 year data record (1995-2010). The dotted line shows the maximum and minimum value observed during the entire data record.

tween autumn 2010 and spring 2011 was among the lowest in the NH (see also Hurwitz et al., 2011), but was still higher than typically seen in respective seasons in the $\mathrm{SH}$, including the perturbed Antarctic vortex in winter 2002 (e.g. von Savigny et al., 2005b). As a result, ozone transport from its source regions in the tropical stratosphere into the mid- and high latitudes of the Northern Hemisphere was weaker between autumn 2010 and spring 2011 than in other years, and polar stratospheric temperatures were lower, favouring conditions for large polar ozone loss. The Arctic winter 2009/2010, is located at the upper end of the range of winter planetary wave activity (Fig. 3). In this winter the Brewer-Dobson circulation was particularly strong (coinciding with an extremely negative Arctic Oscillation phase) resulting in relatively high 


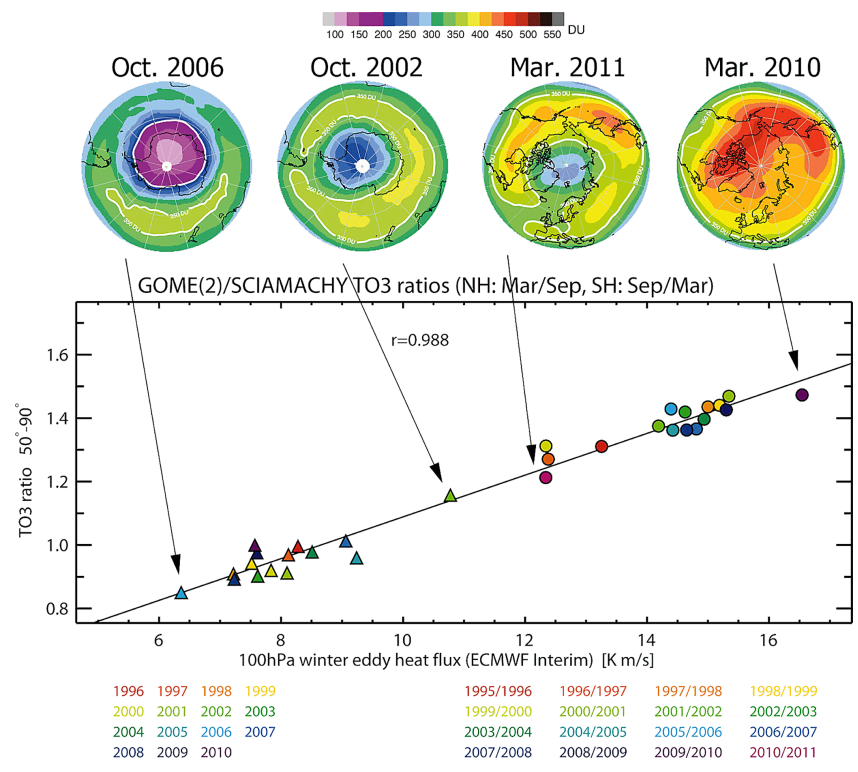

Fig. 3. Correlation between winter mean eddy heat flux and springto-fall ozone ratio over the polar caps (update from Weber et al., 2011). Triangles are data from the SH; circles from the NH. The winter mean eddy heat flux is calculated by averaging the monthly mean eddy heat flux from 43 to $75^{\circ}$, separately, in each hemisphere and average over the months September-March in the NH (for NH data) and March-September in the SH (for SH data).

temperatures and high ozone throughout the $\mathrm{NH}$ (Steinbrecht et al., 2011; Dörnbrack et al., 2012; Strahan et al., 2013).

\subsection{Stratospheric column ozone in March 2010 and 2011}

The consecutive winters 2010 and 2011 are good examples of largely varying ozone levels over the Arctic in the most recent years. In winter-spring 2010, Arctic ozone was unusually high, whereas a year later the so-far largest ozone loss over the Arctic was reported (e.g. Kuttippurath et al., 2010; Steinbrecht et al., 2011; Manney et al., 2011; Strahan et al., 2013). Figure 4 compares partial columns of mean stratospheric ozone in March 2010 and 2011 from SCIAMACHY and GOME-2 with results from the isentropic CTM. In March 2010 and 2011, ozone was maximum above the North American and West Siberian landmasses. Minimum ozone is found in March 2011 above the North Atlantic between Greenland and Scandinavia, whereas in March 2010 minimum ozone is found over Scandinavia and north-eastern Europe. In March 2010 total ozone was very high even near the pole. This effect is attributed to the poleward meridional transport of ozone-rich air from lower latitudes, because a major warming in February 2010 initiated the breakdown of the polar vortex (e.g. Kuttippurath et al., 2010; Dörnbrack et al., 2012). In 2011, the vortex was stable until mid-March, so that ozone was largely depleted north of approximately $75^{\circ} \mathrm{N}$. In particular with respect to GOME-2, the model re-

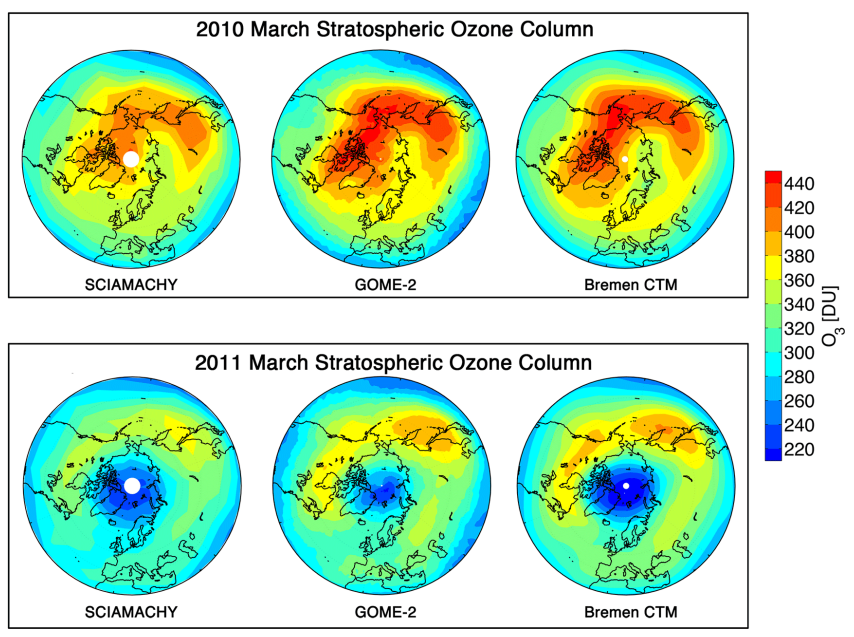

Fig. 4. Mean stratospheric columns of ozone in March 2010 (top) and 2011 (bottom) as obtained from SCIAMACHY in limb-viewing geometry (left), the nadir-viewing scanning spectrometer GOME-2 and as inferred from chemistry transport model calculations (right). For GOME-2 the stratospheric column was obtained by subtracting tropospheric ozone (climatological values) from the measured total ozone.

produces well the observed c-shape pattern of the high ozone in the collar region and the low ozone over the northern Atlantic and Europe.

From GOME-2 total ozone the tropospheric ozone climatology by Fortuin and Kelder (1998) was subtracted in order to obtain a comparable partial ozone column for the stratosphere. The model's lower boundary coincides with the lowest altitude retrieved from SCIAMACHY limb-scatter ozone measurements $(\sim 10 \mathrm{~km})$, also the top of atmosphere is approximately equal to the highest altitude for which ozone was retrieved from limb, so that these two data products do not substantially differ in their vertical extent, hence their vertical columns, as in Fig. 4, are directly comparable. With this in mind, and considering that ozone above $55 \mathrm{~km}$ contributes to around $0.1 \%$ or less to the total column, it turns out that the model has an approximately $10 \%$ positive bias in the stratospheric ozone column, compared to SCIAMACHY limb measurements. This bias is primarily reflected in high ozone values over the landmasses north of $40^{\circ} \mathrm{N}$. In contrast, the model shows a good agreement with the data of the two instruments in regions where column ozone is low. Sensitivity studies have shown that the modelled ozone column in the 2 years may vary by approximately $10 \%$ depending on the approach used to model the vertical transport of stratospheric trace constituents. Results presented in this work are confined to model runs conducted with interactive heating rate calculations (MIDRAD), though apparent polar column ozone is larger than in simulations with prescribed ERA-Interim heating rates. The latter shows approximately $10 \%$ lower column ozone in the collar region between 40 and $70^{\circ} \mathrm{N}$ in both winter-spring periods. Although 
this agrees better with SCIAMACHY limb-measured column ozone, modelled ozone profiles, respectively loss, are better represented in the interactive model. The bias between GOME-2 and SCIAMACHY can most likely be attributed to the relatively simple approach used to obtain a stratospheric column from the measured GOME-2 total column.

\section{Temporal development of $\mathrm{O}_{3}, \mathrm{NO}_{2}$ and $\mathrm{BrO}$ vortex averages}

\subsection{SCIAMACHY limb measurements}

Individual chemical processes, governing ozone loss in the Arctic stratosphere, are difficult to separate from dynamical processes, which largely determine the interannual variability of polar ozone and its synoptic day-to-day changes. In this section, we use SCIAMACHY limb observations to illustrate the temporal development of ozone and related chemical constituents in the winter-spring Arctic vortex in 2010 and 2011, each being representative of a warm and cold Arctic winter stratosphere, respectively. Chemically induced ozone loss is inferred from limb measured ozone mixing-ratio profiles.

\subsubsection{Limb vortex averages}

Figure 5 shows the temporal evolution of the vortex-averaged ozone mixing ratio from January to April 2010 and 2011 on isentropes from 400 to $700 \mathrm{~K}$. This figure also depicts the evolution of the SCIAMACHY limb-scatter measured and vortex-averaged $\mathrm{BrO}$ and $\mathrm{NO}_{2}$ mixing ratios, two gases, which are largely involved in the chemical cycles destroying ozone. As discussed previously, vortex averages have been calculated from limb profiles located inside the vortex. This is where the modified potential vorticity on a given isentrope is larger than $38 \mathrm{PVU}$. To reduce sampling differences to respective model data, discussed in Sect. 4.3, we consider only measurements south of $80^{\circ} \mathrm{N}$ latitude. Additionally, averages from less than 10 samples are excluded from the analysis. As a result, the morphology of ozone and related species within the vortex until the end of April is well obtained as shown. Although in late January 2010 a major stratospheric warming initiated the breakdown of the Arctic polar vortex, it remained intact throughout March (von Hobe et al., 2013). Even in April 2010, we obtain clearly more than 10 samples on most occasions above the $475 \mathrm{~K}$ isentrope.

The large ozone destruction in 2011 is obvious when comparing the two ozone time series (Fig. 5, top panels). In contrast, the time series of the other two species, $\mathrm{BrO}$ and $\mathrm{NO}_{2}$, appear much more homogeneous and, in principle, do not differ distinctly between the 2 years. Inferred ozone losses, shown in the bottom panels of Fig. 5, develop in different altitude regions of the vortex. In the warm vortex 2010 , ozone is decomposed mainly above the $550 \mathrm{~K}$ isen- tropic level, whereas in the cold vortex 2011 the largest loss is found below.

In $2011, \mathrm{O}_{3}$ was as low as $0.5-1.5 \mathrm{ppmv}$ after 12 March 2011 below the $550 \mathrm{~K}$ isentropic level until the vortex became unstable and broke down. Differences in the vortex dynamics in the 2 years explain the obvious differences seen in the ozone time series above $550 \mathrm{~K}$. In 2010, when the vortex was much weaker than in 2011, the variability in the ozone profiles is much larger. This is because the descent of air is stronger in weaker vortices (Rosenfield et al., 1994), implying that the variability in the descent rates increases, and with it the variability of the descent of ozone from above. The vortex-mean ozone time series highlights another not previously investigated detail. This is a sudden reduction of ozone down to $1.5 \mathrm{ppmv}$ or less, which occurred during an 8 day period, commencing 21 January 2011. This episode and its origins are discussed in Sect. 7.

As mentioned above, the temporal behaviour of the limbmeasured $\mathrm{BrO}$ vortex averages is relatively similar in these 2 years. There is a sharp decrease in the mixing ratios in April of both years, which is more pronounced in 2011. This transition also changes the vertical structure of the sampled profiles. During the winter months and during March, the profiles do not exhibit distinct vertical gradients, mixingratios observed in April strongly increase from 7 to $12 \mathrm{pptv}$ between 500 and $650 \mathrm{~K}$. Below the $500 \mathrm{~K}$ isentropic level, even lower mixing ratios of 3 pptv are found in April 2011. Both characteristics are clearly linked to the weakening of the vortex-mixing barrier in spring, allowing the meridional exchange of air from lower latitudes, where $\mathrm{BrO}$ mixing ratios are smaller. An additional contribution comes from the marked seasonal cycle of $\mathrm{BrO}$ in the high- and mid-latitude stratosphere, which is strongly coupled to the seasonal cycle in $\mathrm{NO}_{2}$ (e.g. Richter et al., 1999). This is confirmed by ground-based DOAS observations of $\mathrm{BrO}$ over Harestua $\left(60.22^{\circ} \mathrm{N}, 10.75^{\circ} \mathrm{E}\right.$; Theys et al., 2009) and the OSIRIS limb-sounder on-board the Odin satellite (McLinden et al., 2010). The $2011 \mathrm{BrO}$ time series also shows a transient reduction in the mixing ratios during the second half of January 2011 below the $525 \mathrm{~K}$ isentrope, which correlates well with the transient reduction in the vortex-average ozone time series. This relationship is analysed in more detail in Sect. 7.

During polar night most of the stratospheric $\mathrm{NO}_{\mathrm{x}}$ is converted into reservoir species, mainly $\mathrm{N}_{2} \mathrm{O}_{5}$ and $\mathrm{HNO}_{3} . \mathrm{NO}_{\mathrm{x}}$, and hence $\mathrm{NO}_{2}$, will be recycled when sunlight returns to the polar regions in late-winter and spring. This is clearly seen in the vortex-average $\mathrm{NO}_{2}$ mixing ratios from SCIAMACHY limb measurements (Fig. 5). Below the $550 \mathrm{~K}$ isentrope, $\mathrm{NO}_{2}$ mixing ratios are smaller than $0.1 \mathrm{ppbv}$ throughout January. The replenishment of vortex $\mathrm{NO}_{2}$ in winter-spring 2011 is substantially delayed when compared to 2010 conditions. This is because meridional exchange with $\mathrm{NO}_{2}$-rich air from mid-latitudes was suppressed by the strong polar vortex mixing barrier. Additionally, the descent of air from the upper stratosphere and mesosphere, where $\mathrm{NO}_{\mathrm{x}}$ is more abundant, 
Winter-Spring SCIAMACHY Limb Vortex Averaged VMR
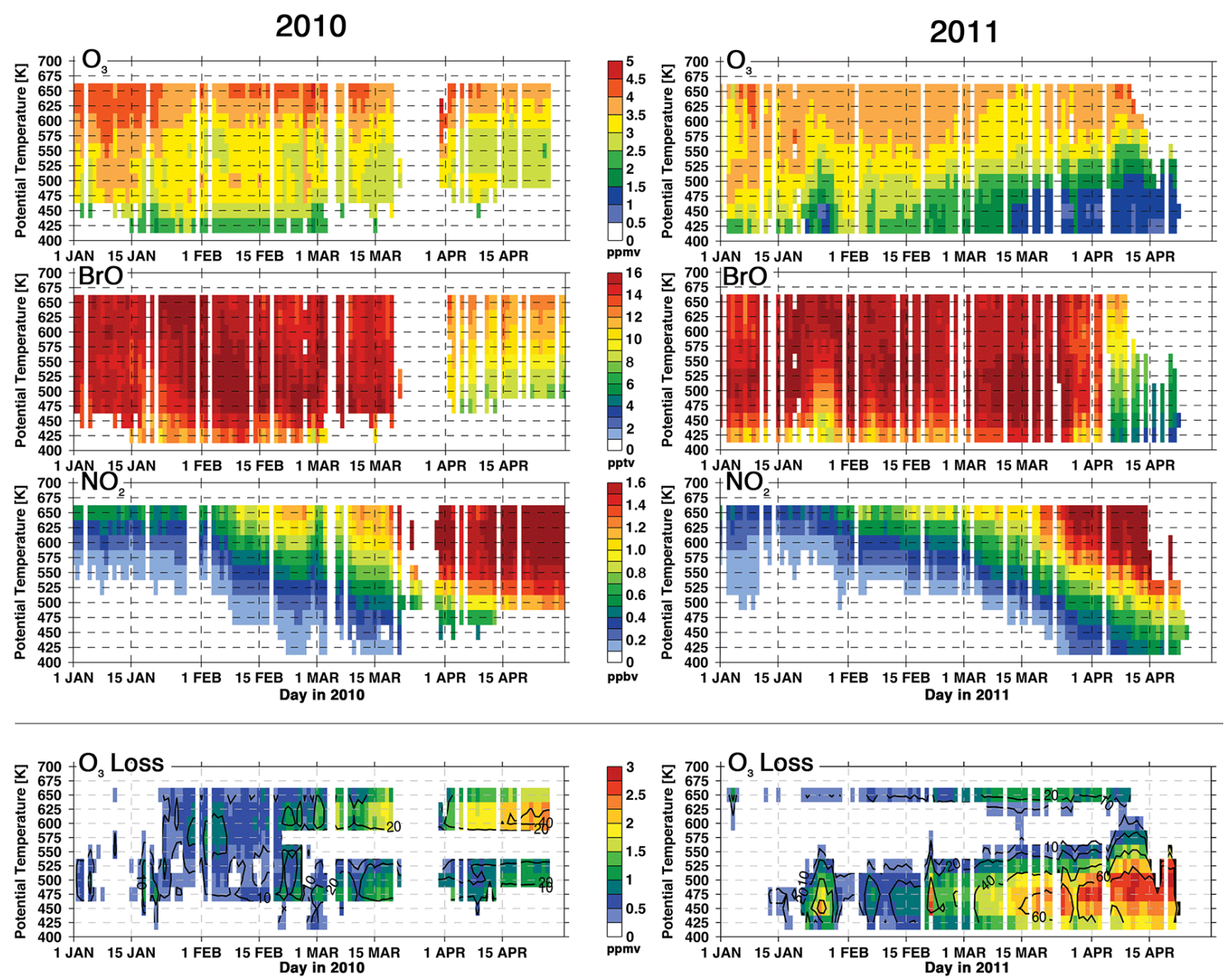

Fig. 5. Evolution of $\mathrm{O}_{3}, \mathrm{BrO}$ and $\mathrm{NO}_{2}$ in the lower stratospheric Arctic polar vortex during the first 4 months of 2010 (left column) and 2011 (right column), obtained from SCIAMACHY limb observations. Bottom panels show corresponding chemical ozone losses obtained by using the method of Eichmann et al. (2002). Only those SCIAMACHY limb profiles are taken into account where the modified potential vorticity (UKMO) exceeds 38 MPVU and the solar zenith angle is between 75 and $88^{\circ}$. Values from less than 10 samples have not been included and were blanked in the panels. Volume mixing ratios are colour shaded, black contour lines in the bottom panels denote relative ozone loss as percentages.

was slower. Furthermore, in winter-spring 2011 the strong and persistent occurrence of PSC effectively denitrified the Arctic stratosphere (e.g. Manney et al., 2011; Khosrawi et al., 2012; Pommereau et al., 2013), also keeping the $\mathrm{NO}_{2}$ level low until the end of March 2011 (see also Sects. 5 and 6).

\subsubsection{Inferred ozone loss}

By applying the vortex-averaging method of Eichmann et al. (2002) to SCIAMACHY limb-scatter ozone profiles, we estimate the chemically induced ozone loss below the $550 \mathrm{~K}$ isentropic surface of up to $77 \%$ in April 2011, relative to ozone values measured on the first day of the year (bottom panels of Fig. 5). In the short period between 21 and 29 January 2011, we infer an ozone reduction of $60 \%$, on av- erage, which quickly recovered afterwards. It is known that such rapid ozone reductions and subsequent recoveries are dominantly dynamical features, so-called "ozone mini-hole" events (e.g. Weber et al., 2002). In Sect. 7 we discuss this in more detail.

Compared to the behaviour in 2010, in the warmer and weaker Arctic polar vortex ozone loss barely exceeded $20 \%$ below the $550 \mathrm{~K}$ isentropic surface. Above, however, we infer an ozone depletion of up to $40 \%$ during spring 2010 (relative to values on the first day of the year). Due to the slower descent of air in the strong vortex 2010/2011, this upper layer of ozone loss is located above the $650 \mathrm{~K}$ isentrope, and hence, is barely visible in our analysis. Above the regions where halogen-driven catalytic cycles remove ozone, $\mathrm{NO}_{\mathrm{x}}$ 
photochemistry is predominantly responsible for ozone depletion (Osterman et al., 1997). This process is stronger during warm winter years, when the vortex is weaker, because less denitrification on fewer PSC is taking place. Air from the upper stratosphere is descending faster and the lateral mixing of $\mathrm{NO}_{2}$-rich air from mid-latitudes is more likely than in cold winter-spring periods, when the vortex mixing barrier is much stronger (Rosenfield et al., 1994; Konopka et al., 2007). As shown e.g. by Sonkaew et al. (2013) and Kuttippurath et al. (2010), these $\mathrm{NO}_{\mathrm{x}}$-driven catalytic ozone losses above the $550 \mathrm{~K}$ isentropic level are frequently observed in the Arctic polar stratosphere in late winter and spring.

Manney et al. (2011) reported a chemically induced ozone loss in the order of at least $2.5 \mathrm{ppmv}$ between 470 and $550 \mathrm{~K}$ by end of March 2011 from Lagrangian chemical transport model studies and ozone measurements from Aura/MLS and the March network of ozonesondes. This number is consistent with our estimate, which is $2.5-3 \mathrm{ppmv}$ at the end of March. Our SCIAMACHY-based loss estimate, however, is slightly $(0.5 \mathrm{ppmv})$ lower above $525 \mathrm{~K}$ as that of Manney et al. (2011). The onset of the catalytic ozone destruction occurs around 1 February 2011 in both studies. Kuttippurath et al. (2012) report a vortex-average ozone loss of $2.4 \mathrm{ppmv}$ over $370-850 \mathrm{~K}$ in late March and early April 2011 from MLS, also using the passive trace technique as in Manney et al. (2011) but simulated by a different CTM. Arnone et al. (2012) reported vortex-averaged ozone reductions down to 0.6 ppmv in early April 2011 at $18 \mathrm{~km}(\sim 430 \mathrm{~K})$ from MIPAS aboard Envisat, in good agreement with our data. The corresponding ozone loss also match our estimates, although based on a different method, taking correlative MIPAS $\mathrm{N}_{2} \mathrm{O}$ observations into account.

Kuttippurath et al. (2010) and Wohltmann et al. (2013) show comparable ozone loss morphologies from MLS for winter-spring 2009/2010 and infer maximum ozone loss of $0.9 \mathrm{ppmv}$ at $475 \mathrm{~K}$ and $\sim 0.94 \mathrm{ppmv}$ (with a maximum loss of 1.9 ppmv at $600 \mathrm{~K}$ ), respectively. Compared to our time series of vortex-average ozone loss in 2010, which has a distinctly layered structure, Kuttippurath et al. (2010) show a relatively homogeneous ozone loss over a broad range of isentropes from around $450 \mathrm{~K}$ to well above $700 \mathrm{~K}$ after midJanuary 2010. Our estimate of $\mathrm{NO}_{\mathrm{x}}$ ozone catalytic loss is about a factor of two larger than in their study.

Reported column ozone losses over the Arctic in March and April of the 2 years vary depending on the definition of the vertical column and the areal averages. Monthly averages from the SCIAMACHY limb sounder have been discussed already in Sec. 3 in comparison to GOME-2 and the CTM. Some recent studies attempted also to infer the chemical contribution to total and/or partial ozone loss observations. Sinnhuber et al. (2011) inferred a column ozone loss of up to 120 DU towards end of April 2011 from MIPAS observations over $380-550 \mathrm{~K}$. These values are principally confirmed by corresponding model simulations conducted with an isentropic CTM having a similar set-up to ours used in this study (Sinnhuber et al., 2003; Aschmann et al., 2011), but differently initialised and driven by meteorology from the ECMWF operational analysis. Sinnhuber et al. (2011) also showed that MIPAS ozone at the $475 \mathrm{~K}$ isentropic surface reduced to 1.5 ppmv in early April 2011, which is rather at the upper end of our estimate. These values are consistent with those discussed by Manney et al. (2011), who inferred vortex-average column ozone deficits of $\sim 120$ DU in lateMarch from MLS observations. Also for MLS, Kuttippurath et al. (2012) calculate a column loss of 115 DU over 350$550 \mathrm{~K}$, and $131 \mathrm{DU}$ over $370-850 \mathrm{~K}$. Strahan et al. (2013) examined dynamical effects and chemical contributions from MLS-observed ozone profiles in 2011 and report a vortexaverage partial column loss of $84 \pm 12 \mathrm{DU}$ that originates from halogenated catalytic cycles in the lower stratospheric column between $\sim 370$ and $550 \mathrm{~K}$. For 2010, Kuttippurath et al. (2010) infers a 42 DU column ozone loss from MLS between 350 and $550 \mathrm{~K}$, and $60 \mathrm{DU}$ between 350 and $850 \mathrm{~K}$. The latter value corresponds to the cumulative column ozone loss of 79 DU that was reported by Wohltmann et al. (2013) also for MLS in the stratosphere above $350 \mathrm{~K}$.

Uncertainties in the ozone loss inferred from SCIAMACHY limb observations are primarily attributed to the rather idealistic assumptions about transport processes inside the vortex, which do not take mixing processes along its edge into account. As a consequence, ozone loss may be overestimated, as e.g. shown by Grooß et al. (2008) for the moderately cold Arctic winter-spring 2002/2003. This may in particular affect loss estimates in the lowest regions of the vortex where the permeability of the boundary is larger (Manney et al., 1994). Singleton et al. (2005) noted a similar discrepancy of the vortex-average method related to the occurrence of sudden stratospheric warming events, which substantially dilute air inside the vortex remnants (e.g. Manney et al., 2008; Konopka et al., 2007). Sonkaew et al. (2013), however, showed that the vortex-averaging method applied to SCIAMACHY limb observations succeeded in delivering ozone loss estimates similar to those inferred from other instruments in warmer and dynamically more active Arctic winters. Uncertainty in the computed daily change in ozone arises from assumptions and uncertainties in the computed diabatic descent over the sampling points. However, the largest error source in vortex-average accumulated ozone loss is the deviation of the observed daily ozone mixing ratios at the sampling points, as demonstrated by Eichmann et al. (2002) and Sonkaew et al. (2013) for the cold Arctic winters $1999 / 2000$ and 2004/2005. Since the deviation of the measurements is clearly associated with the number of samples within the sunlit area of the vortex, the uncertainty in the loss estimate decreases as the number of measurements increases during the course of the winter and spring. 
2011 Winter-Spring SCIAMACHY Occultation VMR Inside Vortex
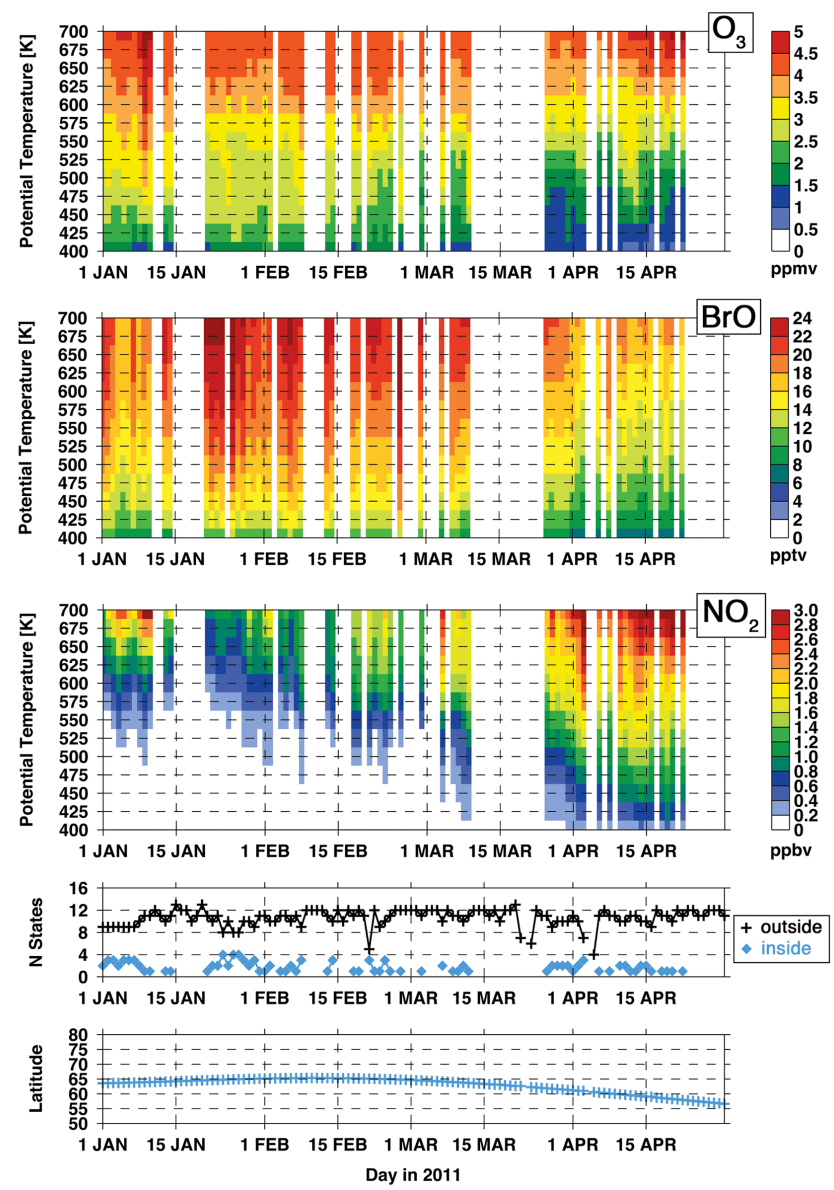

Fig. 6. Evolution of $\mathrm{O}_{3}, \mathrm{BrO}$ and $\mathrm{NO}_{2}$ in the lower stratospheric Arctic polar vortex from 1 January 2011 to 30 April 2011 obtained from SCIAMACHY solar-occultation observations. Only measurements within the polar vortex (modified potential vorticity $>38$ PVU) are considered. The number of respective occultation measurements inside and outside the vortex, as well as the latitude of measurement, are shown in the bottom panels. Note the different plotting range of $\mathrm{BrO}$ and $\mathrm{NO}_{2}$ compared to limb and model vortex averages (Figs. 5, 8).

\subsection{SCIAMACHY solar-occultation measurements}

To complement our results obtained from the limb-scatter measurements shown in Fig. 5, we retrieved $\mathrm{O}_{3}, \mathrm{BrO}$, and $\mathrm{NO}_{2}$ profiles from SCIAMACHY solar-occultation measurements (Fig. 6). As for limb profiles, in our analysis we consider only those occultation profiles located within the vortex. Since solar-occultation measurements were performed at different local times (sunset around 18:00 LT, compared to morning local time around 10:00 LT for limb geometry), the respective vortex averages are obtained from different geolocations compared to the limb data. This is demonstrated clearly in Fig. 7, which shows $475 \mathrm{~K}$ potential vorticity maps for 2 days during winter 2011 together with geolocations of limb and solar-occultation measurements. The vortex edge is approximately at $38 \mathrm{PVU}$, here indicated by yellow contour shades. Occultation measurements are indicated by the larger circles, limb measurements are the smaller dots. White limb dots mark measured profiles outside the vortex, those used in the vortex averages are marked in black. On 23 February the vortex is nearly concentric and close to the pole (stable vortex). On this day only four solar-occultation profiles, from locations over central Siberia contribute to the time-series shown in Fig. 6, compared to 130 profiles in limb-scattering geometry. On 15 April, the situation is very different. The vortex is largely displaced towards central Siberia, stretching down to regions over south-eastern Europe. During that day most limb profiles are concentrated near the pole, thus only a few limb profiles capture the vortex region south of $70^{\circ} \mathrm{N}$. In that case five solar-occultation profiles lie within the vortex, and not necessarily close to its edge as on 23 February 2011.

It is important for comparing the constructed solaroccultation measured $\mathrm{BrO}$ - and $\mathrm{NO}_{2}$-vortex averages with the limb observation results (Fig. 5) that the local time of the solar-occultation measurement is quite different from the limb measurement. Both gases have a strong diurnal cycle, with steepest gradients appearing at sunrise and sunset. Solar-occultation measurements are performed during local sunset so that we cannot rule out that the obtained vortex-averaged time series of the two gases may illustrate a different state of the vortex with respect to daytime limb measurements.

Since occultation measurements are performed during local sunset when much of the daytime $\mathrm{BrO}$ has already been partitioned into nighttime reservoir species (mainly $\mathrm{BrONO}_{2}$ ), we would expect to retrieve lower $\mathrm{BrO}$ mixing ratios from solar-occultation measurements and higher mixing ratios from limb measurements. On the contrary, Fig. 6 shows larger mixing ratios in $\mathrm{BrO}$ and also in $\mathrm{NO}_{2}$, compared to limb (Fig. 5). $\mathrm{O}_{3}$ mixing ratios are only slightly larger above the $625 \mathrm{~K}$ isentrope $(\sim 25 \mathrm{~km})$. This quantitative disagreement arises from the above-mentioned spatio-temporal sampling differences of the two methods. In the latitudinal belt of the $\mathrm{NH}$, where the occultation measurements are performed, stratospheric column amounts of the three species are larger than further poleward in the period we analysed (e.g. Sinnhuber et al., 2002; McLinden et al., 2010; Theys et al., 2011), so that the average from all profiles sampled within the vortex is inherently larger than that of respective limb measurements.

Qualitatively, the temporal evolution of the time series obtained from limb-scatter and solar-occultation measurements are quite similar, but we identify also interesting differences: (i) although compared to limb vortex averages, the variability of the shown occultation-measured mixing ratios is larger in the upper layers (above $550 \mathrm{~K}$ ) and also during spring when the large ozone loss occurs, we cannot infer the low ozone period commencing 21 January 2011 in the occultation time series below $550 \mathrm{~K}$. However, noticeably low 


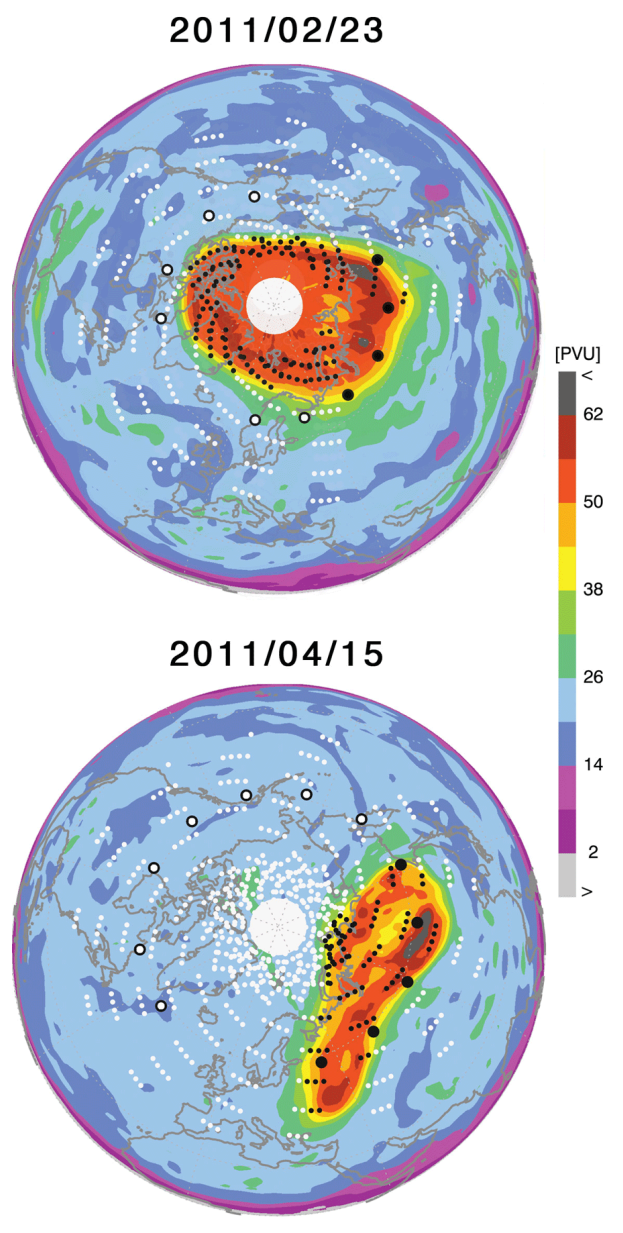

Fig. 7. Polar stereographic projection of the UKMO potential vorticity at the $475 \mathrm{~K}$ isentrope. It also depicts the location of SCIAMACHY limb measurements (small dots) in comparison to SCIAMACHY solar-occultation measurements (large dots), relative to the location and shape of the polar vortex on 2 days in winter-spring 2011. The edge of the polar vortex is at approximately 38 PVU modified potential vorticity. On 23 February (top), around the onset of the chemical ozone depletion, the vortex had an almost circumpolar shape whereas on 15 April 2011 (bottom) it was highly distorted and shifted towards the Eurasian continent. Measurements lying within the vortex are shaded black, locations outside are shaded white. To better differentiate between limb and solar-occultation measurements outside the vortex, the latter are coated black.

$\mathrm{O}_{3}$ mixing ratios are seen at the $400 \mathrm{~K}$ isentropic surface also in January and February 2011. These sporadically occurring events may be caused by mixing processes across the vortex boundary (limb data were not processed at this isentrope) or are effects introduced by the sparse data sampling in the vicinity of the vortex boundary. (ii) In the occultation time series, we observe also a strong anticorrelation between $\mathrm{BrO}$ and $\mathrm{NO}_{2}$ during the temporal evolution of the vortex. The $\mathrm{BrO}$ abundance decreases from the end of January 2011 at approximately the same rate as the $\mathrm{NO}_{2}$ abundance in the vortex increases. A similar behaviour is also seen in our model calculations (Sect. 4.3, Fig. 8). The decline of the $\mathrm{BrO}$ mixing ratios begins at the bottom of the vortex and proceeds upwards into the middle stratosphere, where $\mathrm{BrO}$ is relatively insensitive to seasonal variations in the stratospheric $\mathrm{NO}_{2}$ abundance (e.g. McLinden et al., 2010). This is a robust feature of the BrO seasonal cycle in the high-latitude polar stratosphere, shifting the photochemical equilibrium from $\mathrm{BrO}$ towards $\mathrm{BrONO}_{2}$ between spring and autumn. A similar behaviour has been inferred from ground-based DOAS measurements (e.g. Richter et al., 1999; Theys et al., 2009), limbscatter measured $\mathrm{BrO}$ profiles from the OSIRIS instrument (McLinden et al., 2010), and is also consistent with studies of the BASCOE CTM on the total inorganic bromine budget of the stratosphere (Theys et al., 2009).

Although from a photochemical point of view, the strong anticorrelation between $\mathrm{BrO}$ and $\mathrm{NO}_{2}$ is better captured by the solar-occultation time series, sampling issues limit the representativeness of the method to capture the compositional mean state of the Arctic polar vortex. However, solaroccultation measurements have a high signal-to-noise ratio and many potential instrumental effects cancel in the ratio used to calculate the measured transmission.

\subsection{Reproducing limb observations using a CTM}

\subsubsection{Modelled vortex averages}

From the stratospheric isentropic CTM we constructed vortex averages for $\mathrm{O}_{3}, \mathrm{BrO}$ and $\mathrm{NO}_{2}$ in a similar way as for the limb observations (Fig. 8). For each isentropic model level between 419 and $662 \mathrm{~K}$ we averaged only those grid cells south of $80^{\circ} \mathrm{N}$ where the modified PV was larger than 38 PVU (indicating the vortex edge) and the solar zenith angle during SCIAMACHY overpass was between 75 and $88^{\circ}$. As seen in Fig. 8, the timing of the onset of decreasing ozone mixing ratios as well as layers where this decrease occurs, i.e. below the $550 \mathrm{~K}$ isentropic surface, are well reproduced in 2011. However, ozone drops below 1.5 ppmv 1 week earlier in the model, around 5 March. In comparison, the observations show this around 12 March 2011 (Fig. 5). Above 550 K, the CTM tends to overestimate ozone mixing ratios inside the vortex. The period of low $\mathrm{O}_{3}$ below $550 \mathrm{~K}$ in mid-January 2011 is not well reproduced in the CTM, which is discussed in more detail in Sect. 7.3. The situation in 2010 is well reproduced by the model, though with a weaker variability.

It can be seen from Figs. 5 and 8 that the model vortex averages of $\mathrm{BrO}$ and $\mathrm{NO}_{2}$ are biased low in both years compared to SCIAMACHY limb observations. For BrO, this low bias is most pronounced at lower isentropes. Also, the daily variability of the model $\mathrm{BrO}$ time series is much weaker than in the limb observations.

With the return of sunlight, polar $\mathrm{NO}_{2}$ is converted from its reservoir species $\mathrm{N}_{2} \mathrm{O}_{5}$. Although the timing of the onset of this photochemical regeneration is well reproduced by the CTM, the general low bias in the model $\mathrm{NO}_{2}$ does 

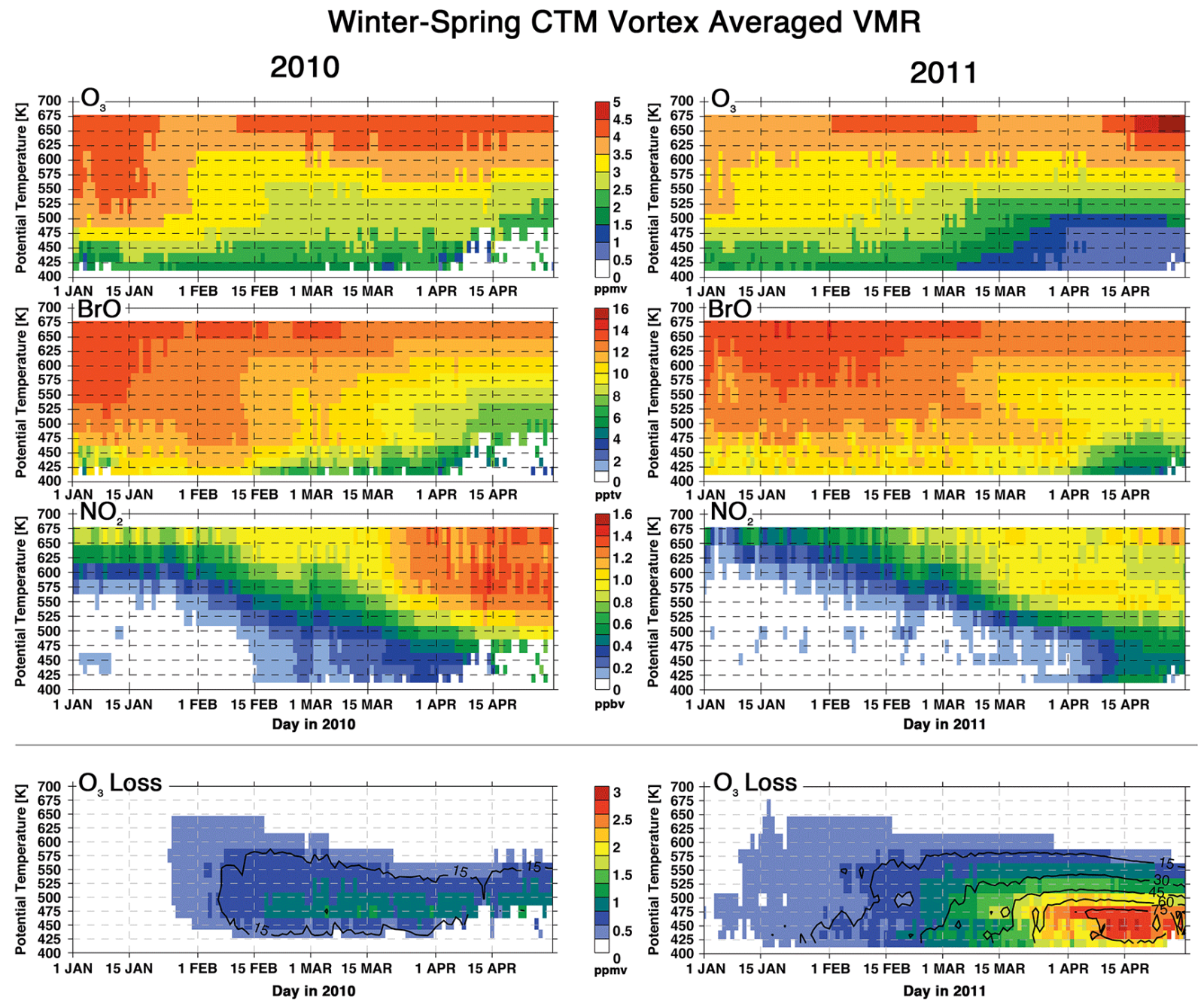

Fig. 8. As in Fig. 5, except for the respective CTM simulations. Here, relative ozone losses are interpreted relative to the volume mixing ratio of a quasi-passive ozone tracer which is only affected by large-scale photochemistry, not considering heterogeneous reactions.

not account for the return of springtime polar $\mathrm{NO}_{2}$ levels as seen in the limb vortex averages. In April 2011, the CTM shows approximately half of the $\mathrm{NO}_{2}$ measured by SCIAMACHY limb, but in April 2010 the low bias is less distinct and in the order of a third. The lower $\mathrm{NO}_{2}$ mixing ratios in 2011 shift the chemical equilibrium of the formation reaction of bromine nitrate $\left(\mathrm{BrONO}_{2}\right)$ towards $\mathrm{BrO}$, so that the modelled vortex-average $\mathrm{BrO}$ abundance in 2011 is 12 pptv larger above the $500 \mathrm{~K}$ isentrope than in 2010. It also delays the decrease in the $\mathrm{BrO}$ mixing ratios, compared to 2010 conditions. A similar gradual decrease is not seen in the limb time series. In contrast, limb-measured $\mathrm{BrO}$ is high in February and March of both years, and decreases relatively rapidly, within approximately 1 week, when the vortex becomes unstable.

\subsubsection{Modelled ozone loss}

In the model, polar ozone loss is quantified as the difference between the modelled, chemically fully interactive ozone and a quasi-passive ozone tracer (LINOZ; linearised chemistry without heterogeneous reactions). Resulting ozone losses (Fig. 8, bottom panels) are in good agreement with the estimates based on SCIAMACHY limb measurements (Fig. 5, bottom panels) below the $550 \mathrm{~K}$ isentropic surface. Relative to SCIAMACHY, the modelled ozone loss is overestimated approximately 5\% in April 2011. In contrast, in 2010 the model ozone loss is underestimated by $10-20 \%$ during March and April in this region. The 2010 halogeninduced ozone deficit is no larger than $1.25 \mathrm{ppmv}$ in the model, whereas from limb observations we infer a loss of up to $1.5 \mathrm{ppmv}$. However, the onset of the period when ozone loss continuously exceeds $0.75 \mathrm{pptv}$ is quite similar in the model and limb data sets in 2010 (between 15 and 
17 February). However, in 2011 the CTM ozone degrades at a significantly slower rate than that estimated from limb observations. Apart from the transient ozone reduction in January 2011, SCIAMACHY ozone loss is permanently larger than 0.75 ppmv after 15 February at the 450 and $475 \mathrm{~K}$ isentropic levels. After 20 February ozone loss is seen also at lower isentropes. And in March 2011 it reached the $500 \mathrm{~K}$ isentropic level. On 21 February 2011 we infer a temporally maximum loss of 2.5 ppmv. In the CTM simulation, however, a persistent ozone loss larger than $0.75 \mathrm{ppmv}$ is found after 23 February between 425 and $525 \mathrm{~K}$. The region of largest loss above 2 ppmv is confined to the 425 and $475 \mathrm{~K}$ isentropes in April 2011 in the CTM simulations, whereas from limb observations we infer the largest loss between 450 and $500 \mathrm{~K}$. As mentioned above, relative to the simulated and observed ozone fields, the maximum ozone loss in 2011 is approximately $5 \%$ larger in the CTM simulation.

One striking difference between the ozone loss from SCIAMACHY and the CTM is the absence of the $\mathrm{NO}_{\mathrm{x}}-$ driven ozone decomposition layer above the $550 \mathrm{~K}$ isentropic level in the model. This is not caused by the above-mentioned general underestimation of polar $\mathrm{NO}_{2}$ in the CTM, it is rather an inherent effect of the approach used to infer ozone loss in the model. The loss due to $\mathrm{NO}_{\mathrm{x}}$ is parametrised in the LINOZ scheme and thus impacts the linearised ozone tracer, which represents the reference of the model's loss estimate. Consequently, due to the use of this pseudo-passive ozone tracer, the layer of $\mathrm{NO}_{\mathrm{x}}$ related ozone loss cannot be determined (Singleton et al., 2005). As mentioned before, we discuss in Sect. 7.3 why we do not infer the transient ozone reduction in the second half of January 2011 from the model time series of vortex-average ozone, although it is a distinctive feature in the respective SCIAMACHY limb time series.

Our modelled ozone losses are consistent with other model studies. Vertically resolved and vortex-averaged time series of ozone and respective ozone losses have been shown by Kuttippurath et al. (2010) for the period 2004/20052009/2010. Kuttippurath et al. (2012) examined the winterspring 2010/2011 in comparison to 1996/1997. Wohltmann et al. (2013) performed sensitivity studies of the halogen catalytic destruction of ozone in 2009/2010. All three studies infer ozone loss from the fully passive tracer technique (see Singleton et al., 2005, for a review). It is noted that other studies on the severe Arctic ozone loss in 2011 also refer to model simulations. Most of them do not address heightresolving time series, and they are not discussed in more detail in the following. We refer the reader to Sect. 3 above, where column ozone from our model is shown in relation to SCIAMACHY limb observations and the climatology of the long-term GSG total ozone column data set.

The magnitude of our model ozone loss in the warm winter-spring 2009/2010 is in agreement to Kuttippurath et al. (2010), except that the largest loss of $1-1.25 \mathrm{ppmv}$ is confined to isentropes below $550 \mathrm{~K}$. This results from the use of the pseudo-passive ozone tracer, as discussed above.
The onset of ozone loss in 2010 is seen at least 1 week earlier in Kuttippurath et al. (2010), hence agrees well with their loss inferred from MLS profiles within the vortex, similar to our SCIAMACHY limb ozone loss estimates (Fig. 5). The 2010 modelled ozone loss by Wohltmann et al. (2013), also comparing to MLS, agrees well with Kuttippurath et al. (2010) and reaches $0.94 \mathrm{ppmv}$ in the layer between 400 and $550 \mathrm{~K}$. Even though the Wohltmann et al. (2013) model exhibits a $\sim 5-10 \%$ high bias in ozone mixing ratios in the altitude region where PSC can form. However, in their model the maximum ozone loss is $1.4 \mathrm{ppmv}$, slightly above $600 \mathrm{~K}$, from MLS they infer a maximum loss of $1.9 \mathrm{ppmv}$ at $600 \mathrm{~K}$. The authors claim that besides uncertainties in the modelling of chemical processes their ozone loss bias is mainly attributable to the dynamics of the modelled tracer advection, since both ozone loss estimates (CTM and MLS) rely on the same modelled passive ozone fields.

The morphology of the 2011 ozone loss as modelled by Kuttippurath et al. (2012) is also in agreement with our simulation. Our model shows an approximately $0.35 \mathrm{ppmv}$ larger loss at the $450 \mathrm{~K}$ isentrope only on five days in mid-April 2011. The onset of ozone loss larger than $0.5 \mathrm{ppmv}$ around 1 February is found around $500 \mathrm{~K}$ in the Kuttippurath et al. (2012) simulation. The onset in our simulation is rather located at the lowest isentropes. Loss above 2 ppmv is simulated by both models in the second half of March 2011 until the end of April. But in our time series, the maximum loss is not found above the $475 \mathrm{~K}$ isentrope, as it is the case in the simulation of Kuttippurath et al. (2012). As discussed in Sect. 4.1.2, the 2011 ozone loss calculated by Sinnhuber et al. (2011), utilising a CTM largely identical to ours, agrees well with MIPAS observations. However, their loss, shown for the $475 \mathrm{~K}$ isentrope only, is about $10 \%$ smaller than in our simulation and that of Kuttippurath et al. (2012). Ozone loss reported by Manney et al. (2011) in their comprehensive analysis of 2011 Arctic winter conditions relies on passive ozone fields from a CTM (passive tracer subtraction technique) that has been also used in the above-mentioned study by Wohltmann et al. (2013). In their paper, Manney et al. (2011) showed the morphology of the MLS-inferred ozone loss but not the respective morphology from the CTM simulation.

Differences between the simulated and observed ozone loss are principally attributed to uncertainties in the measurements themselves, as discussed above. They may also relate (i) to uncertainties in modelling the ozone transport in the two ozone loss approaches, (ii) to an incomplete representation of ozone chemistry in the model, or (iii) arise from the geographic sampling of the data. Data sampling differences have been linked by Singleton et al. (2007) to overestimated ozone loss in a CTM simulation of the 2004/2005 Arctic winter-spring (during that time the largest Arctic ozone loss recorded) in comparison to estimates from ozone profile observations from various satellite instruments. The authors also argued that model shortcomings in the reproduction of synoptic-scale processes, in particular subsequently to 


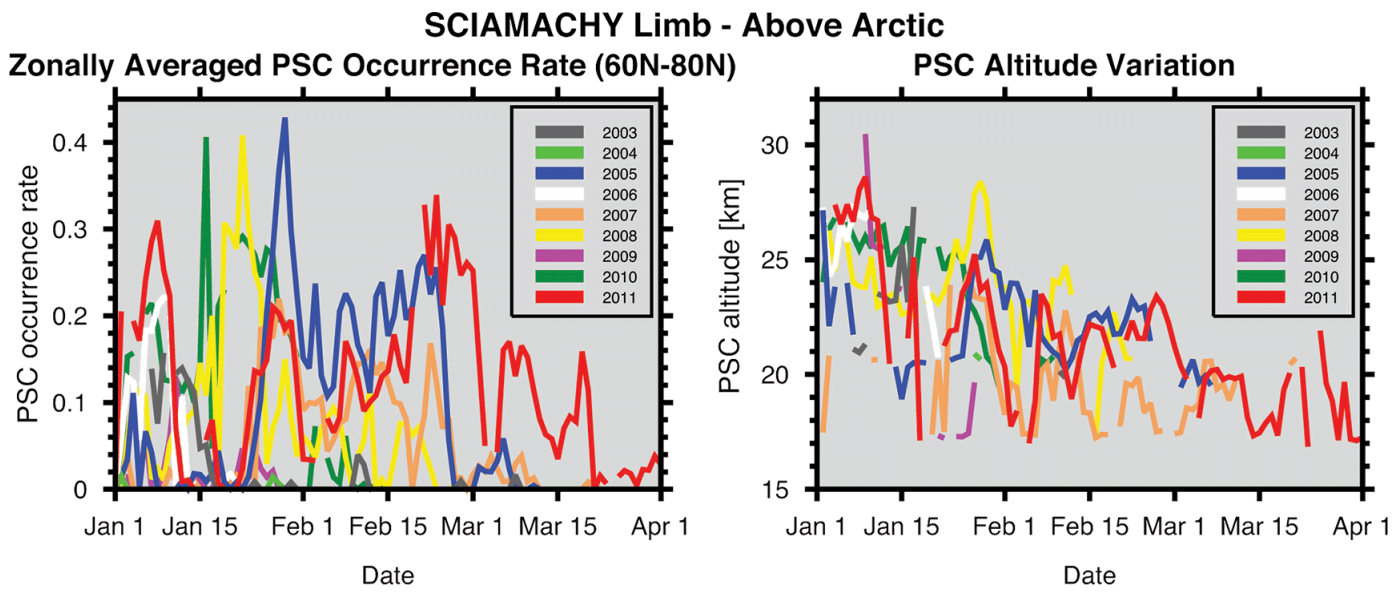

Fig. 9. PSC occurrence rate (a) and PSC altitude (b) obtained from SCIAMACHY limb observations since 2003. For clarity reasons only years with frequent PSC occurrences are displayed in the right panel.

stratospheric major or final warmings, may have impacted the magnitude of the simulated ozone loss.

Our model vortex averages, and the calculated temporal evolution of the inferred ozone losses, are also thought to reflect sampling differences in the illuminated areas of the vortex. Because the local time of the SCIAMACHY overpass is a discrete value in the model, it is resolved according to its latitudinal resolution. This translates into a bias of the SZA, used as filter criterion to collect the data. Even if the model ozone profiles would perfectly match the observations inside the vortex, this deviation in the sampled area of the sunlit vortex region would induce a notable difference in the averaged values, in particular when distinct horizontal gradients appear in the tracer fields. This source of uncertainty has also been noted by Rex et al. (2006) in a comparison of ozone loss estimates from various techniques, including the vortex-average method, for the cold 2004/2005 Arctic winter.

The difference between model and "measured" ozone loss may also be explained by shortcomings of the model to reproduce specific processes that determine the ozone variability in the Arctic stratosphere. It has been shown in several studies that the externally driven large-scale horizontal transport of tracers associated with the Brewer-Dobson circulation as well as the internally calculated vertical transport across isentropes are supposed to be captured well by our CTM (e.g. Kiesewetter et al., 2010b; Aschmann et al., 2009, 2011). Both the observed interannual and the day-today variability of Arctic column ozone are well reproduced (see also Sect. 7). Both ozone loss methods use the MIDRAD radiation scheme to calculate heating rates in order to simulate the vertical transport of ozone inside the polar vortex. Therefore, differences in the rate of ozone descent rely on differences in the driving meteorological fields and may have an impact on the inferred ozone loss. A quantification of this bias is difficult and will be the subject for further study.
Another uncertainty exists in the modelling of processes that are associated with the catalytic cycles removing ozone, in particular chlorine activation and denitrification (WMO, 2011). Recently, Wohltmann et al. (2013) showed that such uncertainties impact modelled column ozone loss by approximately $10 \%$. Their study with the ATLAS model, a Lagrangian CTM, was performed for the comparatively warm Arctic stratosphere in winter-spring 2009/2010. Respective deviations in the ozone loss profiles stay within $30 \%$ between the 471 and $507 \mathrm{~K}$ isentropic levels, but are shown for a single day only (30 March 2010). How deficiencies related to chlorine activation and denitrification in our CTM may be responsible for an underestimation of ozone loss in one year (2010) and an overestimation in the other year (2011), cannot be explained by the findings of Wohltmann et al. (2013), because in both years denitrification was much stronger than in other years of the past decade (e.g. Khosrawi et al., 2012, see Sects. 5 and 6).

\section{SCIAMACHY limb observations of PSC}

The meteorological conditions in the 2011 Arctic winterspring polar vortex favoured the formation of PSC. Figure 9 shows the temporal evolution of the daily mean PSC occurrence rate (left panel) and daily averaged PSC altitude (right panel) - both in the $60-80^{\circ} \mathrm{N}$ latitude range - for several Arctic winters including 2010/2011 from 1 January to 1 April as inferred from SCIAMACHY limb-scatter observations. The PSC occurrence rate is given by the ratio of the number of SCIAMACHY measurements with PSC detections and the total number of measurements - on a given day and within a certain latitude range. The right panel in Fig. 9 demonstrates the impressive PSC descent during the course of winter-spring. This descent is not only attributed to particle sedimentation, to a large extent it reflects the descent of the lower stratospheric temperature minimum, as has 
been demonstrated for the southern hemisphere by von Savigny et al. (2005a). PSC altitudes derived from SCIAMACHY correspond to PSC top altitudes, not to centroid altitudes. The cloud thickness cannot be inferred using the method applied.

SCIAMACHY measured strong PSC occurrences in 2005, 2008, 2010 and 2011, each with distinct characteristics of onset, daily variation, persistence and maximum occurrence rates. Only in 2005 and 2011 did the observed PSC occurrence rates increase until 25 February. In 2005, no strong occurrences have been measured after that date. In 2011, PSC persisted even well into March, unusually long for Arctic conditions (Manney et al., 2011; Arnone et al., 2012), but after 25 February occurrence rates were significantly smaller and decreasing. The years 2005 and 2011 were also the only 2 years of the studied PSC record, when no major stratospheric warmings occurred and distorted the polar vortex during winter (Kuttippurath and Nikulin, 2012; Khosrawi et al., 2012), so that PSC could develop rather continuously. In contrast, in the other years of the record major warmings significantly impacted the spatio-temporal development of the Arctic polar vortex. While in 2005, 2008, and 2010 strongest PSC occurrences have been detected in the second half of January, in 2011 we found the strongest occurrences before 12 January and in the second half of February. Although the maximum occurrence rates in 2005, 2008, and 2010 were about $20 \%$ larger than the maximum rates observed in 2011, the overall amount of PSC formed during the course of winter and spring 2011 was even larger than in the winter before, with the consequence that denitrification of the Arctic stratosphere was the strongest recorded in the last decade (Khosrawi et al., 2012). This is interesting insofar, as denitrification was already on a record high the year before, even though the winter 2009/2010 has been classified as rather warm in a climatological sense (e.g. Dörnbrack et al., 2012). However, exceptionally low temperatures in the Arctic stratosphere from mid-December 2009 to mid-January 2010 fostered the formation of PSC for 1 month (Khosrawi et al., 2011).

Since SCIAMACHY measurements depend on sunlight, the variability of the measured PSC occurrence rates in January may be attributable to reduced illumination conditions and the associated reduced sampling of SCIAMACHY limb measurements inside the polar vortex. Furthermore, one cannot deduce the exact onset of the PSC season in each winter. The spaceborne CALIOP lidar, for instance, first indicated PSC in the 2009/2010 winter on 15 December 2009 (Khosrawi et al., 2011). In the following winter, the first PSC have been identified by the instrument on 23 December 2010 (Khosrawi et al., 2012). Arnone et al. (2012) report significant PSC occurrences even at the beginning and in the second half of December 2010 from MIPAS/Envisat observations. Despite the above-mentioned limitations, Sonkaew et al. (2013) emphasised the high correlation between the February mean SCIAMACHY PSC occurrence rates and PSC volume estimates from other studies (Rex et al., 2006;

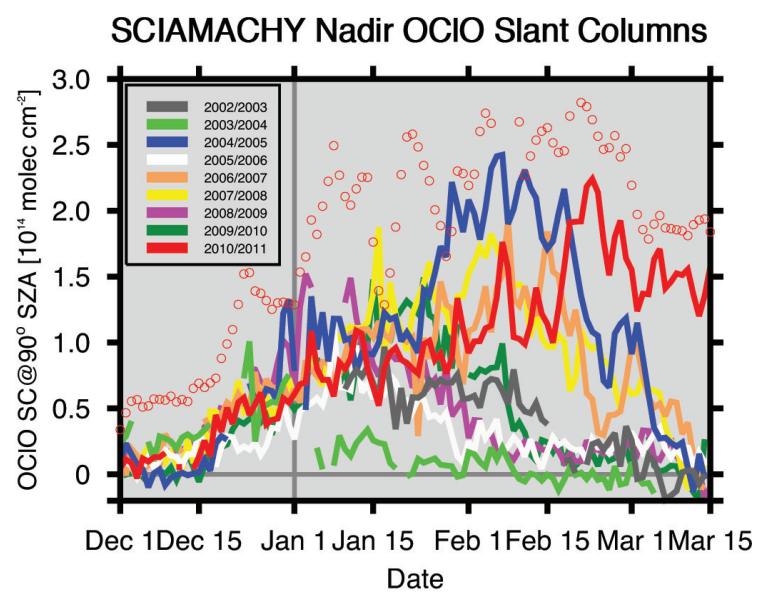

Fig. 10. SCIAMACHY nadir observations of OClO slant columns since winter $2002 / 2003$ at $90^{\circ}$ SZA. CTM calculations for winterspring 2010/2011 are shown as red circles and were sampled at $90^{\circ}$ SZA at the time of SCIAMACHY overpass.

WMO, 2011) and respective polar vortex volumes from reanalysis data. Furthermore, the CALIOP instrument also provides information about the PSC type, which cannot be determined with our approach relying on SCIAMACHY limb measured colour indices. However, our PSC observations in winter-spring 2010 and 2011 correlate well with the decrease in the polar $\mathrm{HNO}_{3}$ and $\mathrm{N}_{2} \mathrm{O}$ abundances, as measured by Aura/MLS and Odin/SMR (Khosrawi et al., 2011, 2012; Manney et al., 2011). There is no doubt that denitrification played a large role for the ozone loss in 2011; however, recently, Strahan et al. (2013) argued that the unexpected dynamical situation of the polar stratosphere may be accountable for around one-third of the ozone destroyed in the Arctic vortex in March and April 2011.

\section{SCIAMACHY nadir measurements and ground-based DOAS measurements}

\subsection{Chlorine activation}

While OClO is not directly involved in ozone depletion, it is formed by reaction of $\mathrm{BrO}$ and $\mathrm{ClO}$ which are both key substances in catalytic ozone removal. While BrO concentrations do not vary strongly from year to year, $\mathrm{ClO}$ concentrations do, making $\mathrm{OClO}$ an indicator for chlorine activation.

As shown in Fig. 10, OClO slant columns at $90^{\circ} \mathrm{SZA}$ from SCIAMACHY nadir measurements vary strongly from year to year. After an initial increase in mid-December, the values remain elevated in January and then decrease up to the end of the observation period in mid-March. This is when $90^{\circ} \mathrm{SZA}$ measurements are no longer available in the ascending part of the orbits. In some years, OClO levels remain elevated up to the beginning of March, while in other years, activation already ends in January. The cold winter in 2010/2011 was 
unique in that $\mathrm{OClO}$ values remained high until the end of observations, indicating persistent chlorine activation. The observed large variability in OClO columns is mainly explained by interannual differences in chlorine activation, resulting from differences in stratospheric temperatures and PSC formation rates. Some additional variability is introduced by the SCIAMACHY satellite observation method at $90^{\circ} \mathrm{SZA}$, which is limited to specific latitude ranges for each day. Depending on the size and deformation of the polar vortex, this can lead to differences in the sampling of the region with activated chlorine.

Our OClO measurements in 2011 are consistent with DOAS observations in Eureka $\left(80^{\circ} \mathrm{N}, 68^{\circ} \mathrm{W}\right.$; Adams et al., 2012). In general they also correspond to the low abundances of the FTIR-measured chlorine reservoir species $\mathrm{HCl}$ and $\mathrm{ClONO}_{2}$ as reported by Lindenmaier et al. (2012) for Eureka. Their compilation of measurements, going back to 1997, also reveals the unique character of the 2011 winterspring, indicating an extensive and prolonged chlorine activation compared to any other year of the record. Arnone et al. (2012) report vertically resolved observations of vortexaverage $\mathrm{ClONO}_{2}$, together with $\mathrm{ClO}$ at the $550 \mathrm{~K}$ isentrope, both retrieved by a two-dimensional tomographic approach from MIPAS. Although not directly comparable with our data, they also indicate strong and persistent chlorine activation throughout February and March 2011 in the altitude regions were PSC are formed. Manney et al. (2011) reported $\mathrm{ClO}$ and $\mathrm{HCl}$ vortex averages for the $485 \mathrm{~K}$ isentrope from Aura/MLS for 2010/2011 in comparison to other years since 2004/2005, as well as for 1995/1996 and 1996/1997 obtained from UARS/MLS. In 2011, the ClO mixing ratio strongly increased until the beginning of March, then declined moderately but remained elevated compared to all other years. This behaviour is different from that reported by Arnone et al. (2012) for $550 \mathrm{~K}$, which shows a less steep gradient before March. Both studies infer that the partitioning of the active chlorine into its reservoirs began in early March. The MIPAS time series of $\mathrm{ClONO}_{2}$ shows a very strong increase after 15 March that coincides well with the decrease seen in their $\mathrm{ClO}$. The increase of MLS-measured $\mathrm{HCl}$ is less distinct in March 2011. However, both data sets are in good qualitative agreement with our OClO nadir slant columns from SCIAMACHY, particularly with respect to the temporal evolution in 2011 and the interannual variability in the measurements.

\subsection{Vertical columns of $\mathrm{NO}_{2}$ from SCIAMACHY nadir measurements}

$\mathrm{NO}_{2}$ is involved in both the catalytic destruction of ozone and in the formation of reservoir species such as $\mathrm{ClONO}_{2}$. Daytime levels of $\mathrm{NO}_{2}$ are mainly determined by day length, which governs the partitioning between $\mathrm{NO}, \mathrm{NO}_{2}$, and its reservoirs, and to a lesser degree by temperature. During polar night, it is converted into $\mathrm{N}_{2} \mathrm{O}_{5}$ and $\mathrm{HNO}_{3}$, which can be incorporated into PSC and thereby be removed from the gas

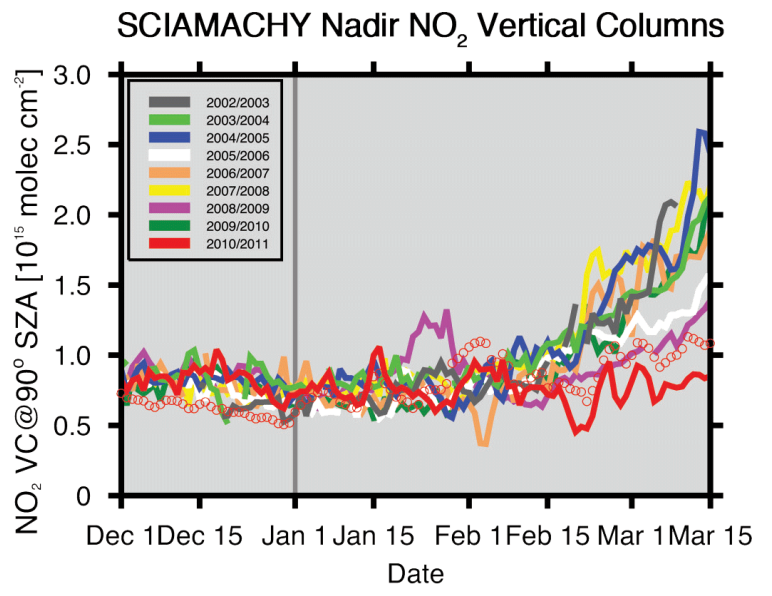

Fig. 11. As in Fig. 10, except for vertical columns of $\mathrm{NO}_{2}$ at $90^{\circ}$ SZA.

phase. Usually, this removal is reversible as PSC evaporate, but if PSC sediment to lower altitudes, persistent denitrification of some atmospheric layers can occur. The removal of $\mathrm{NO}_{2}$ is of particular importance for the length of stratospheric chlorine activation as in its absence the formation of inactive chlorine reservoirs is delayed.

In general, the variability in the $\mathrm{NO}_{2}$ columns is relatively small, mainly because day length is the determining factor. This is illustrated in Fig. 11, where SCIAMACHY $\mathrm{NO}_{2}$ columns are shown for a number of Arctic winters. The main difference between individual years is the onset of the recovery of $\mathrm{NO}_{2}$ columns in spring, and no clear link between years with large chlorine activation and those with late onset of $\mathrm{NO}_{2}$ increase is apparent. However, the cold winter 2010/2011 differs from all previous winters in the sense that no increase in $\mathrm{NO}_{2}$ columns is observed until the end of the observation period (16 March 2011), and $\mathrm{NO}_{2}$ levels are at a record low for every single day after 15 February 2011. In agreement with other satellite observations shown by Manney et al. (2011) and Khosrawi et al. (2012), this indicates that in spring $2011 \mathrm{NO}_{\mathrm{y}}$ was removed from the lower Arctic stratosphere by large-scale denitrification, providing the conditions for strong and persistent ozone depletion.

\subsection{DOAS measurements at Ny-Ålesund}

Ground-based DOAS measurements above the NDACC Koldewey station in Ny-Ålesund (Spitsbergen/Svalbard, $78.55^{\circ} \mathrm{N}, 11.55^{\circ} \mathrm{E}$ ) have been carried out since 1995 , and data from winter-spring periods of 2005, 2008, and 2011 are shown exemplarily in Fig. 12. The time series confirm that the winter-spring of 2011 was exceptional compared to the other 2 years with strong chlorine activation. As already seen in the SCIAMACHY observations (Figs. 10, 11), the winter 2010/2011 was unique in that OClO values remained high until the end of observations shortly after 20 April. Significant levels of $\mathrm{OClO}$ well above the detection limit have 

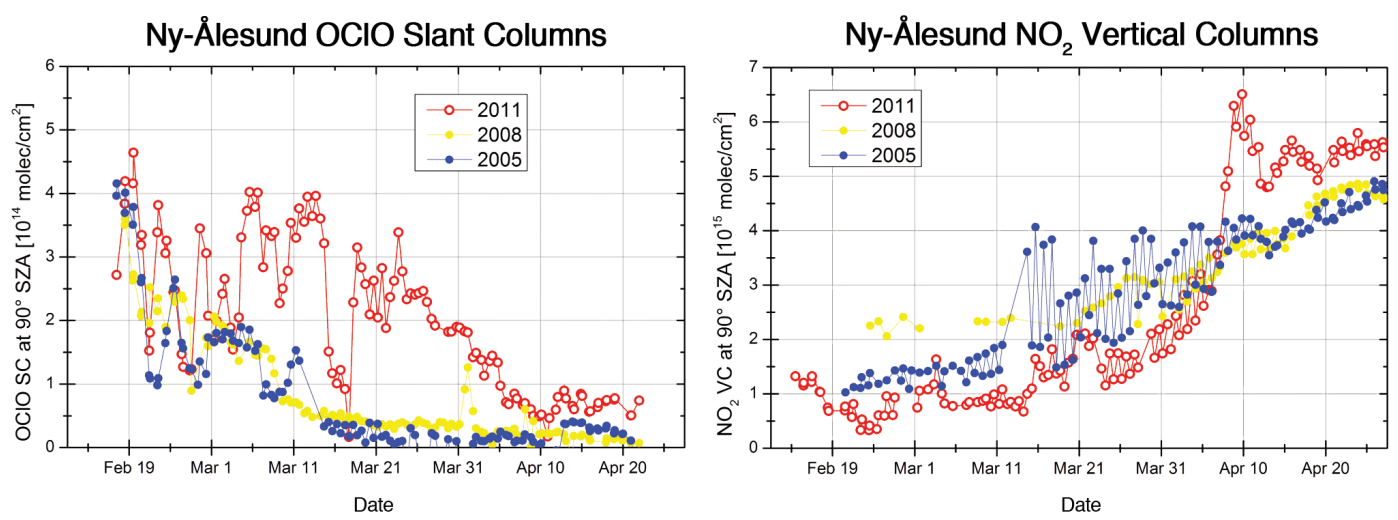

Fig. 12. Ground-based measurements of (a) OClO slant columns and (b) vertical columns of $\mathrm{NO}_{2}$ in $\mathrm{Ny}-\mathrm{A}$ lesund $\left(78.55^{\circ} \mathrm{N}, 11.55^{\circ} \mathrm{E}\right)$ at $90^{\circ}$ SZA for winter-spring period of 2005, 2008, and 2011.

been observed until the beginning of April, indicating chlorine activation about 4 weeks later into spring than in previous years. For $\mathrm{NO}_{2}$ the results are similar. The very low levels indicate efficient denitrification and were seen from the ground-based observations until April 2011 as well.

Vertical columns of $\mathrm{NO}_{2}$ are also reported for 2011 by Pommereau et al. (2013) from the SAOZ network of UVvisible spectrometers at high northern latitudes. They found similar, low total-column amounts for sunrise and sunset measurements inside the vortex until mid-March 2011. They also refer to a rapidly increasing $\mathrm{NO}_{2}$ diurnal cycle thereafter that relates to the late onset of renoxification in 2011, which has not been inferred from the station measurements in previous years.

\section{Low Arctic ozone in January 2011}

The SCIAMACHY limb time series of vortex-averaged Arctic ozone exhibits two periods of low ozone in the winterspring periods of 2011 (Fig. 5, top right panel), as discussed in Sect. 4.1. In addition to the persistently strong halogenrelated ozone depletion in March and April 2011, for several days commencing 21 January 2011 ozone mixing ratios in the Arctic polar vortex dropped on average to values less than $1.5 \mathrm{ppmv}$ below the $500 \mathrm{~K}$ isentropic surface. When the ozone loss, relative to values observed on the first day of year, is inferred from the ozone time series by the vortex-averaging method, the January 2011 low ozone period is apparently also attributable to halogen-driven ozone depletion, similarly to the ozone loss in spring (Fig. 5, bottom panels). But despite the uncertainties in the ozone loss rate estimation, for several reasons it seems unlikely that the January 2011 ozone reduction is primarily caused by chemical processes: (i) although halogen activation is initiated readily with the occurrence of first PSC, the amount of halogens activated until 20 January is most probably not large enough to account for an almost complete destruction of ozone in a relatively thick layer of the vortex; (ii) to explain the sudden drop in the vortex ozone mixing ratios, respective daily ozone loss rates being attributable to halogens need to be more than 10 times larger than those reported for conditions leading to severe ozone depletion over the Arctic or Antarctica; (iii) a chemical removal of ozone cannot be explained by ozone chemistry when a few days later ozone recovers at approximately the same rate as it vanished; (iv) during the period of low ozone, the mixing barrier encompassing the vortex was strong and prevented exchange with surrounding air where ozone was more abundant. This implies that the origin of the transient ozone reduction is different from the causes of ozone loss later in spring. This transient ozone reduction, observed in the data products described above, has not been discussed in other studies on the remarkable 2011 ozone loss in the Arctic. This is probably because most of the previous studies focussed on the ozone behaviour in spring (e.g. Hurwitz et al., 2011; Manney et al., 2011; Sinnhuber et al., 2011; Balis et al., 2011; Arnone et al., 2012; Kuttippurath et al., 2012).

\subsection{Observations and meteorological situation}

In Fig. 13 a 12 day sequence of nadir-measured GOME-2 total ozone is shown, beginning on 20 January 2011, 1 day before low column ozone was observed over central Siberia north of Sakhalin island. This area of low ozone was centred at approximately $140^{\circ} \mathrm{E}, 63^{\circ} \mathrm{N}$ and had an initial extent of about $2000 \mathrm{~km} \times 1000 \mathrm{~km}$ in longitude and latitude (or $1.4 \times 10^{6} \mathrm{~km}^{2}$ ). In the following 6 days the low ozone area approximately doubled in size and moved westwards across the Ural region. On 28 January it moved a few degrees eastwards towards central Siberia, where it dissipated 2 days later. Thereafter, Arctic ozone replenished temporarily until around 6 February. Vortex ozone again declined and remained low for the following 3 months almost, according to the SCIAMACHY limb vortex-averaged $\mathrm{O}_{3}$ mixingratio time series (Fig. 5). This temporarily effect is typical 

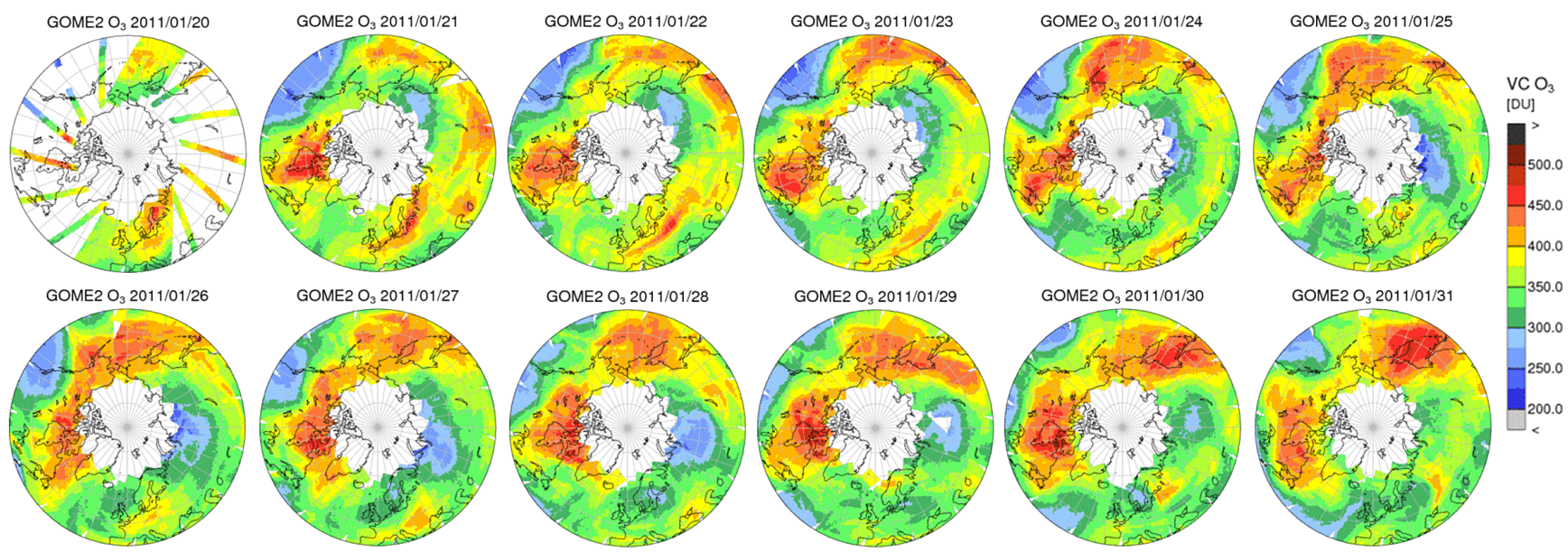

Fig. 13. Daily maps of total ozone measured by GOME-2 between 20 and 31 January 2011. On 21 January 2011 column ozone was substantially decreased by more than 70 DU over central Siberia north of Sakhalin. The low ozone area propagated westward with time reaching the Ural region on 27 January. Then the area of low ozone propagated eastward and dissolved at approximately $90-100^{\circ} \mathrm{E}, 60^{\circ} \mathrm{N}$ on 30 January 2011.
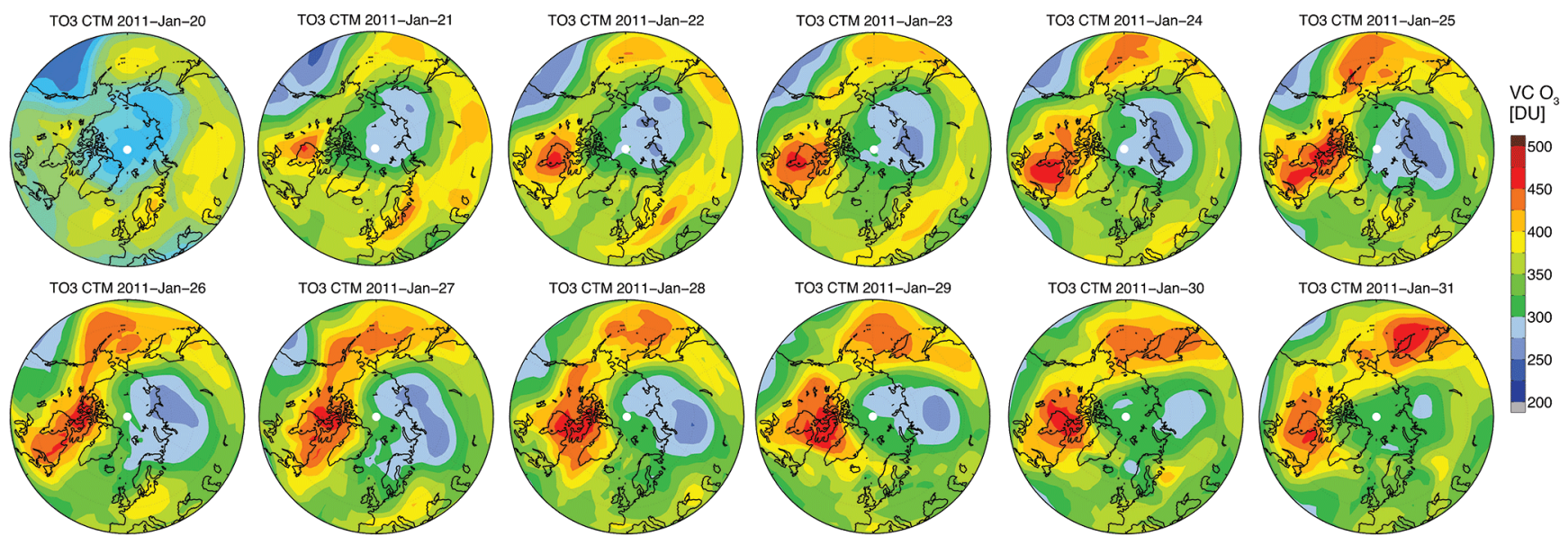

Fig. 14. As in Fig. 13, except for model total ozone. In contrast to Fig. 4, here the Fortuin and Kelder (1998) climatology of tropospheric ozone was added to the model's stratospheric ozone column in order to cover the entire atmosphere.

for so-called "ozone mini-hole" events, which are caused by the intrusion of subtropical air masses with a high tropopause (e.g. Weber et al., 2002).

Although before 21 January 2011 PSC were present in the Arctic stratosphere (Fig. 9), up to this time, not much chlorine had been activated (Fig. 10) that could have led to substantial chemical ozone destruction in mid-January. Hence, such a sudden drop and subsequent rapid recovery of polar ozone can only be explained by dynamical changes.

Sporadically occurring extreme total ozone events on synoptic scales associated with weather systems in the upper troposphere and tropopause region, which change the tropopause height, have been identified and investigated since the 1950s (e.g. Reed, 1950). Such events have been named "ozone mini-holes" (OMH; Newman et al., 1988). Based on TOMS total ozone observations since 1979, James
(1998) found a strong connection between the occurrence of OMHs and the storm-track regions in the North Atlantic and North Pacific and noted a considerably larger frequency of $\mathrm{OMH}$ formation during January to March, with a tendency to later formation the further north the hole appears in the Northern Hemisphere. OMHs are caused in the stratosphere when the tropopause is elevated as a consequence of advection of sub-tropical air moving poleward during the passage of upper tropospheric anticyclones (Krzyścin, 2002). This also implies a lifting of isentropic surfaces above the anticyclonic ridges, which in turn leads to horizontal divergence of ozone out of the stratospheric column, a quasi secondary effect of OMH formation as pointed out by Koch et al. (2005).

In recent years, investigations of mechanisms leading to $\mathrm{OMH}$ formation in the Northern Hemisphere focussed on the northern Atlantic storm track regions where mini-holes 


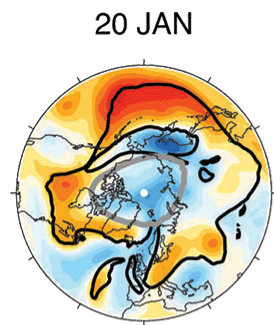

26 JAN

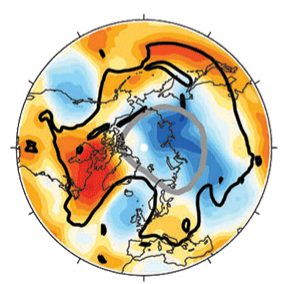

22 JAN

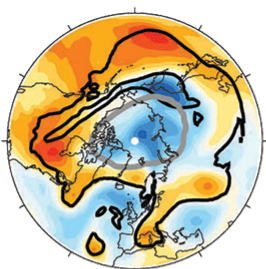

27 JAN

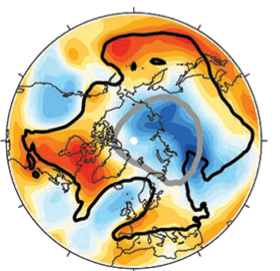

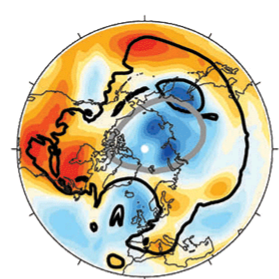

28 JAN

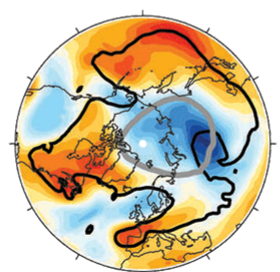

23 JAN

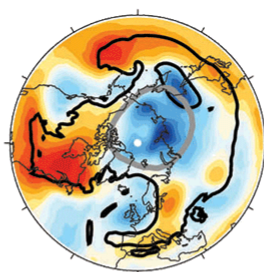

29 JAN

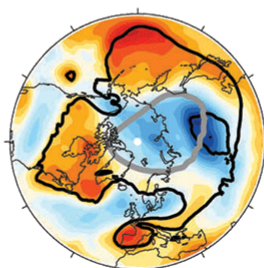

24 JAN

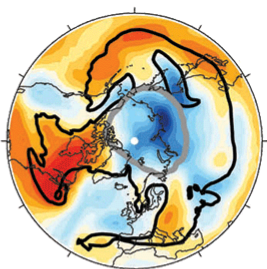

30 JAN

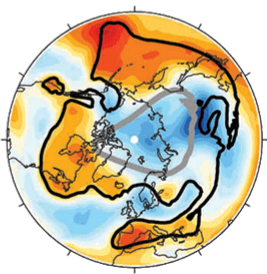

25 JAN

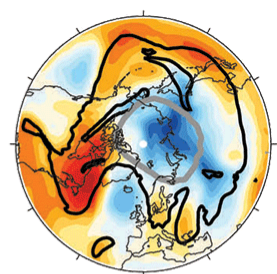

31 JAN

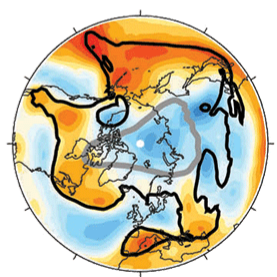

$\begin{array}{llllllllllllllllllll}196 & 198 & 200 & 202 & 204 & 206 & 208 & 210 & 212 & 214 & 216 & 218 & 220 & 222 & 224 & 226 & 228 & 230 & 232 & 234\end{array}$

Fig. 15. Twelve day sequence of temperature at approximate tropopause level ( $315 \mathrm{~K}$ isentropic surface) during the period when large reductions in the GOME-2 column ozone are observed (Fig. 13). The vortex edge is indicated by the gray contour of the 38 PVU potential vorticity at the $475 \mathrm{~K}$ isentrope. The thick black contour denotes the $3 \mathrm{PVU}$ potential vorticity at $315 \mathrm{~K}$, roughly separating polar air masses (low tropopause) from subtropical air masses (high tropopause). All data were obtained from the ECMWF ERA-Interim reanalysis.
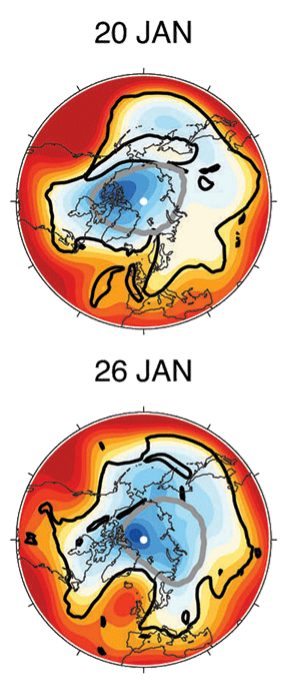

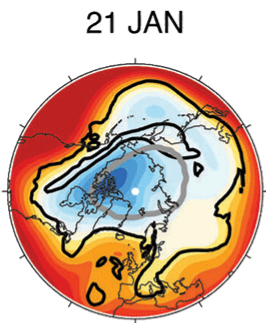

27 JAN
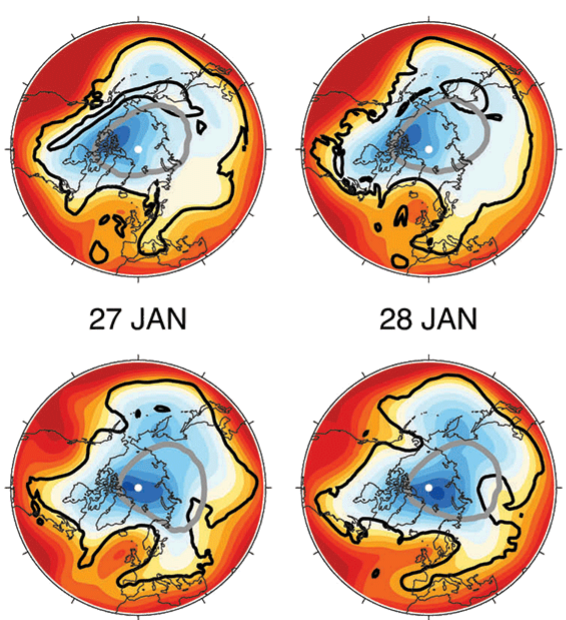

28 JAN
23 JAN

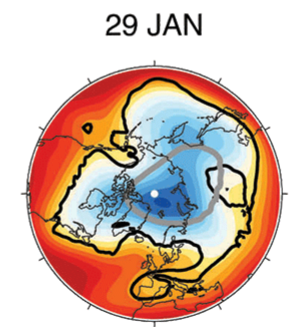

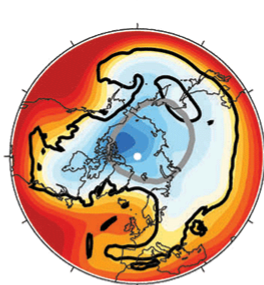

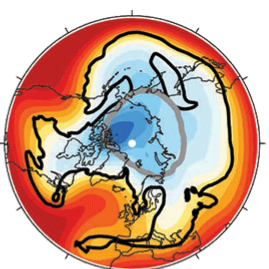

30 JAN

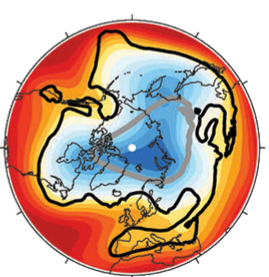

25 JAN

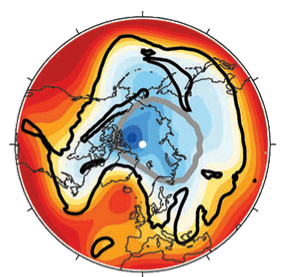

31 JAN

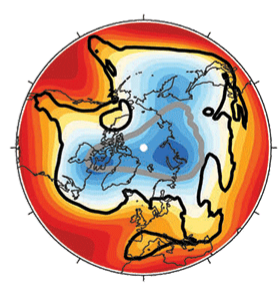

Fig. 16. As in Fig. 15 except for geopotential height.

are predominantly formed. For example, Weber et al. (2002) reported on an OMH formed in February 1996 above Greenland and at the vortex edge. Associated with it were very low stratospheric temperatures (below $188 \mathrm{~K}$, sufficiently low for PSC formation) and low total ozone close to $180 \mathrm{DU}$. This OMH moved within a few days to the northwest and dissipated north of Siberia.
Only a few studies investigated the relationship between OMHs observed over central or eastern Asia (where the January 2011 low ozone is found) and respective atmospheric conditions in those regions. While Liu et al. (2009) studied $\mathrm{OMH}$ conditions over the Tibetan Plateau in December 2003 and linked their occurrence to tropopause elevations associated with the poleward displacement of the 

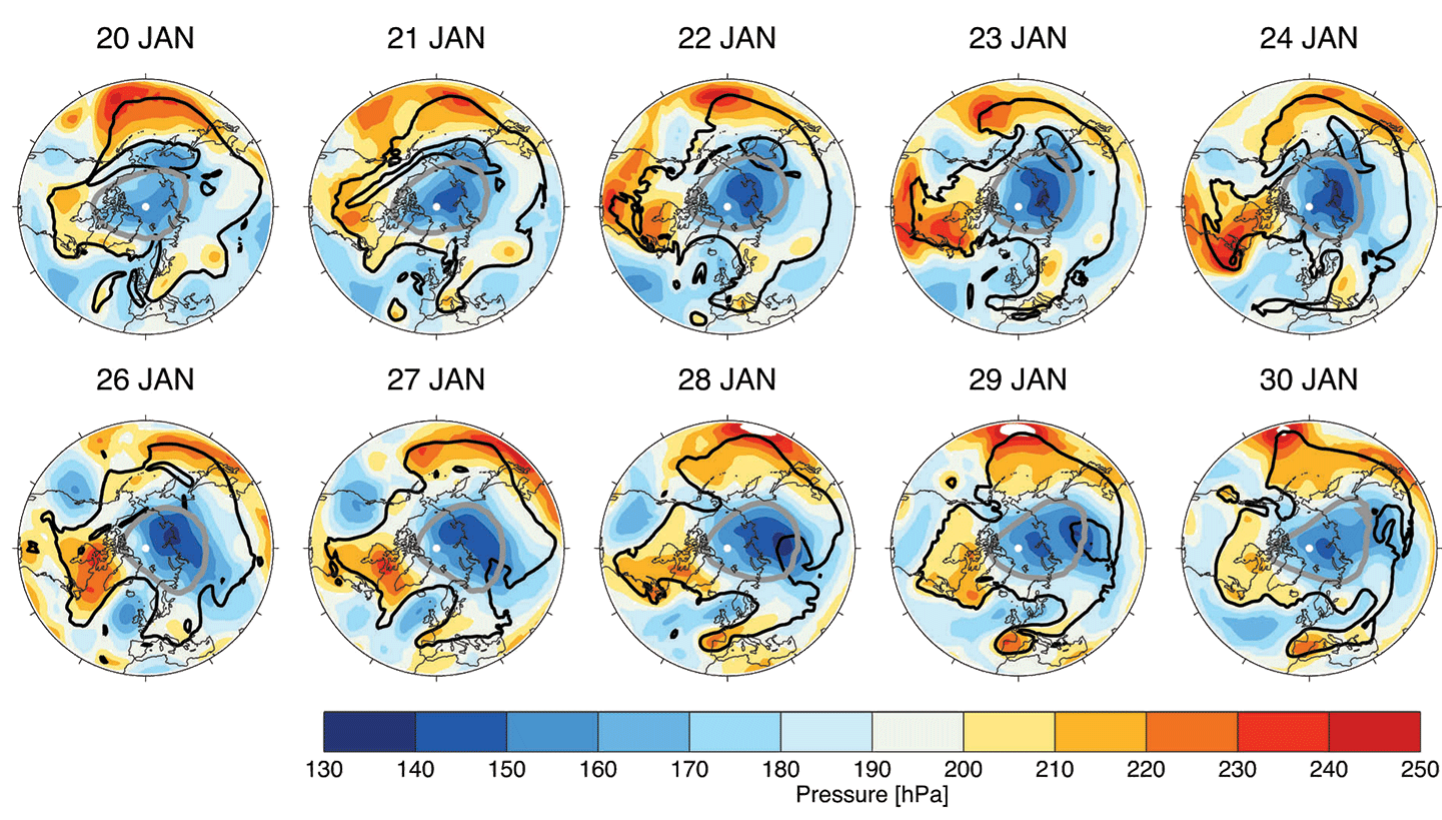
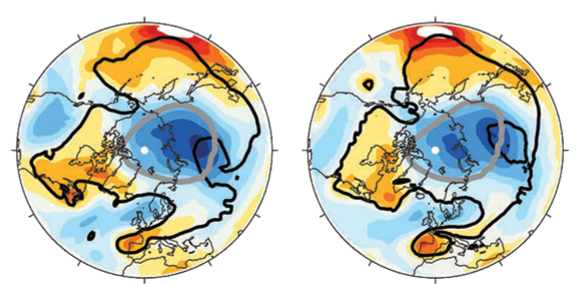

24 JAN

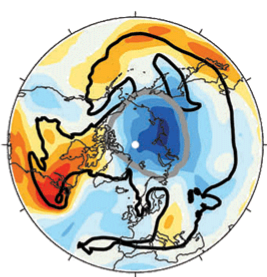

$30 \mathrm{JAN}$

25 JAN

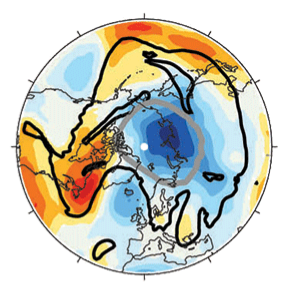

31 JAN
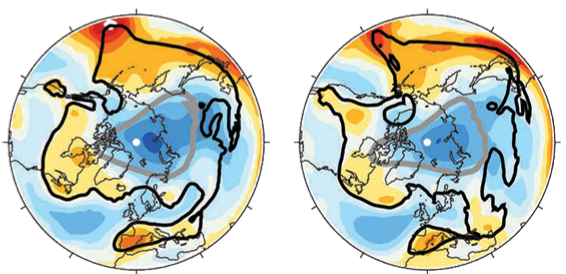

Fig. 17. As in Fig. 15 except for pressure at the $350 \mathrm{~K}$ isentropic surface.

subtropical jet triggered by deep tropical convective heating (Madden-Julian oscillation), Han et al. (2005) found evidence for OMH formation during December 2001, associated with poleward motion of lower stratospheric air east of the Aleutian high. Both studies describe OMHs observed south of $50^{\circ} \mathrm{N}$, not mentioning OMH conditions over Asia further poleward, as seen in January 2011. The low ozone event we are examining here formed initially over East Asian continental regions, clearly west of the northern Pacific storm track, which has been reported as another preferred region of OMH formation (Orsolini et al., 1998). James (1998) identified an increased number of ozone mini-hole occurrences over central Siberia, at least $45^{\circ}$ westward of the northern Pacific storm track region, which agrees closely with the area where the low ozone has been observed in January 2011. However, James (1998) neither described where these OMHs are formed predominately nor in which direction they move when they were formed near the date line.

Not only is the pronounced poleward placement of the January 2011 ozone low somehow remarkable with respect to its potential dynamical drivers, as mentioned above, but a few other characteristics of this particular event are also rather exceptional. Low total ozone over Asia was observed for 10 days in January 2011. This is substantially longer than typical ozone mini-hole lifetimes (1-4 days; Newman et al., 1988). Krzyścin (2002) found OMH lifetimes longer than 6 days only in 6 years between 1926 and 1999. Furthermore, the maximum area of the January 2011 low ozone event is much larger than typical sizes observed in other events. Newman et al. (1988) refer to OMHs extending over $1000-3000 \mathrm{~km}$ (approximately $8 \times 10^{5}$ to $7 \times 10^{6} \mathrm{~km}^{2}$ ), whereas Koch et al. (2005) found that OMHs cover areas of $\sim 5 \times 10^{5} \mathrm{~km}^{2}$. While on the first day of its appearance (21 January) the area of GOME-2 total ozone lower than $300 \mathrm{DU}$ was not larger than $2000 \mathrm{~km} \times 1000 \mathrm{~km}$, covering an area of approximately $1.4 \times 10^{6} \mathrm{~km}^{2}$, during its largest extent on 27 January, the GOME-2 low ozone area covered a region of more than $3400 \mathrm{~km}$ zonally and $2000 \mathrm{~km}$ meridionally, or $3.5 \times 10^{6} \mathrm{~km}^{2}$. As a result of the limitations of satellite observations during daytime, the area where ozone was remarkably low could have been even larger, extending into the polar night. From our CTM simulations, which capture the evolution of this low ozone period in January 2011 quite well (Fig. 14), we obtain that on 27 January 2011 the true meridional extent of the $\mathrm{OMH}$ was as large as its zonal extent, putting its area in the range of $1 \times 10^{7} \mathrm{~km}^{2}$. This is almost a third larger than values given in literature referring to typical OMH sizes and almost as large as a typical area covered by an Antarctic ozone hole in southern hemispheric spring.

Also remarkable is the motion of the January 2011 low ozone area. In the first 6 days after being detected, it moved westward. In contrast, typical OMHs move in the opposite direction, as a result of associated motion of anticyclones and the jet stream.

In order to examine whether the January 2011 low ozone event is attributable to tropopause disturbances, in Figs. 15-17 the meteorological conditions near the tropopause were investigated. GOME-2 first detected lower ozone over eastern Siberia on 21 January 2011 (Fig. 13). In this region the vortex moved over an area where tropopause temperatures decreased below $205 \mathrm{~K}$ (Fig. 15) as a result of the adiabatic cooling, when the tropopause was elevated from the motion of air passing an anticyclone in the upper troposphere. The tropopause lifting coincides with higher 
geopotential heights (Fig. 16). The imposed lifting of isentropes above the elevated tropopause in this region is also seen in Fig. 17, where the atmospheric pressure decreases at the $350 \mathrm{~K}$ isentropic surface. The synoptic situation did not change until 25 January 2011. During this period, for 3 days (21-23 January) the vortex was located above this region, so that the elevation of isentropes thinned the stratospheric ozone column, and a situation emerged, which is typical for OMHs. At the same time a similar situation established over western Siberia and moved eastward. Approximately over the Ural Mountains, a low-PV fragment is found on 24 and 25 January 2011, indicating a tropospheric ridge, associated with conditions leading to $\mathrm{OMH}$ formation. One day later, a PV streamer indicating a high tropopause started to establish east of the Mediterranean Sea, rapidly moving pole- and eastward, sliding below the vortex 2 days later on 27 January. For the next 2 days, until the 29th, the vortex was located above this relatively large region where the tropopause was elevated.

Between 24 and 26 January a broad band of low temperatures connected the two regions exhibiting an elevated tropopause, approximately across the Siberian coast of the Arctic ocean. Even though the tropopause in this cold region was not distinctly elevated, the vortex-averaged temperature was as low as $195 \mathrm{~K}$ between the tropopause and the $600 \mathrm{~K}$ isentrope over all days when ozone was low in both the GOME-2 total column and the limb vortex average.

Although total ozone mapping from space indicates a rather coherent reduction of the ozone column during an elongated period in late January 2011, the meteorological situation clearly reveals that a superposition of two independently evolving synoptic events in the tropopause region formed two individual situations very similar to those causing ozone mini-holes. The two situations evolved from opposite sides of the Asian continent, both poleward of $60^{\circ} \mathrm{N}$. We conclude that favourable meteorological conditions in both the free troposphere and the lower stratosphere merged the two situations after a few days of development. As a result, it appears as a single Arctic ozone mini-hole, covering large areas of the northern regions of central Siberia. On the basis of all these considerations, we will call this event an "OMH-like situation" in the following sections, where we further discuss its behaviour in relation to our ozone loss estimates.

\subsection{Comparison to a typical OMH condition}

The low ozone event in January 2011 is remarkable as it did not emerge over regions where most frequent $\mathrm{OMH}$ occurrences are found. The meteorological conditions responsible for this low ozone event were similar to those in the northern Atlantic sector, where OMHs are found predominately. From the polar stereographic maps of near tropopause temperature and geopotential height (Figs. 15, 16), a distinct ridge of tropospheric air (3 PV contour) is inferred, which is much larger than the ridges over the Eurasian continent. This large ridge is located over the North Atlantic on all days shown in the sequence. From 26 January 2011 onwards the ridge moved over the British Islands and Scandinavia, later reaching central Europe. The tropopause was distinctly elevated, substantially higher than in the regions where we identified the precursors of the low ozone "pocket" over Asia (Fig. 16). However, during the whole period, those tropopause ridges never moved below the polar vortex, which during the whole period was shifted towards central Asia. Hence, tropopause elevations over the northern Atlantic did not contribute to severe reductions in the stratospheric ozone column in late January 2011. In particular, they did not influence the ozone vortex averages shown in Fig. 5.

Associated with this Scandinavian tropopause ridge is a comparably small ozone mini-hole, which is seen in GOME-2 total ozone between 27 and 30 January 2011. In the relative coarsely resolved CTM (resolution $2.5^{\circ}$ in latitude, $3.75^{\circ}$ in longitude) this $\mathrm{OMH}$ is not well reproduced. Only on 30 January 2011 is the OMH apparent in the CTM (Fig. 14), but a few degrees shifted to the northwest, compared to GOME-2 (Fig. 13).

\subsection{Modelling the January 2011 Arctic low ozone event}

As shown in Fig. 14, the CTM largely reproduces the day-today variability of stratospheric ozone over the Arctic. Only small-scale synoptic features such as the Scandinavian ozone mini-hole around 28 January 2011 are not adequately resolved. Also the magnitude of the reduction in column ozone during the OMH-like situation is not captured well compared to GOME-2 observations. GOME-2 shows ozone as low as $200 \mathrm{DU}$ on several days near the polar night blind spot, whereas the model's total ozone is not lower than 250 DU. This behaviour is attributed to an approximated tropospheric contribution to the total ozone column (see Sect. 3.2).

A respective reduction in the height-resolved and vortexaveraged time series of modelled Arctic ozone in 2011 (Fig. 8, top right panel) is not seen, in contrast to vortex averages from SCIAMACHY limb observations (Fig. 5). Model data have been determined at the local times of SCIAMACHY overpasses and were sampled in a similar manner to that of the limb profiles. The sampled areas are somewhat similar, but not identical to each other. Since in January the limb sounder rather sparsely sampled the vortex, sampling errors in the model ozone fields are tendentially leading to positively biased ozone vortex averages, in particular when ozone is inhomogeneously distributed inside the vortex. As it is the case, for example, when an OMH occurs.

However, model equations are solved on isentropes. In the polar stratosphere, isentropes are invariant to adiabatic processes in the tropopause region and a "thinning effect" in prognostic tracer mixing ratios above a tropopause elevation will not be seen in vortex averages, when the meridional divergence of tracers out of the column is small. When the modelled ozone mixing ratios are converted into number 
densities, the "thinning effect" becomes evident and is in the order of $30 \%$ below the $475 \mathrm{~K}$ isentrope, relative to average values before and after this episode (not shown). As described in Sect. 4.1, the effect is approximately a factor of two larger in the limb vortex averages. Also, in the model, the "thinning effect" in ozone number densities does not extend well into the stratosphere. Projected on geometric altitudes, the effect is not inferable above $18 \mathrm{~km}$, which is slightly below the $425 \mathrm{~K}$ isentrope. Whether meridional divergence above an elevated tropopause is underestimated by the CTM and better resolved in the vortex averages from limb-measured ozone profiles cannot be satisfactorily answered without further work. An underestimation by the CTM seems plausible since the model simulations are done in a relatively coarse horizontal resolution. Numerical diffusion may play a role even though the driving meteorology (ERA-Interim) is reproducing well other dynamical aspects of the OMH-like situation.

\subsection{Implications for vortex-average ozone loss estimates}

As limb, nadir and solar-occultation measurements depend on sunlight, Arctic polar vortex regions north of $\sim 75^{\circ} \mathrm{N}$ have not been observed in the beginning of January 2011. Between 21 and 30 January 2011, the vortex was markedly displaced towards Siberia so that most of the vortex was illuminated by the sun, and was well observed by SCIAMACHY and GOME-2. As described above, the largest part of this sunlit area exhibited low ozone values. A few limb profiles were sampled during this time over regions where the tropopause was not elevated. Those profiles exhibit larger ozone mixing ratios, but they do not contribute much to the daily mean vortex averages. We conclude that the transient reduction of vortex-averaged ozone from limb measurements between 21 and 30 January 2011 is reflecting a real situation.

Conversion of the retrieved number density profiles into mixing ratios on isentropic surfaces involves an error or bias through uncertainties in the gridded meteorological data sets used in this conversion. A few percent bias or uncertainty in temperature and pressure translates mainly into a vertical displacement of the projection from geometric altitudes to isentropes and to a lesser extent into a bias of the magnitude of the estimated "dynamical loss". A $2 \%$ deviation in the meteorology, for instance, yield vertical displacements of the limb vortex-mean mini-hole structure in the order of $10 \mathrm{~K}$. Since the number density to mixing-ratio conversion is proportional $\sim T / p$, a bias in coherent meteorological fields should almost have no effect.

As described above, a transient increase in the PSC occurrence rates (Fig. 9a) has been detected for 7 days commencing 22 January 2011. But a corresponding significant increase in the OClO (Fig. 10) slant columns has not been observed, one could relate to a persistent increase in chlorine activation due to this remarkable OMH-like situation. Hence, a direct link between the OMH-like situation and the chemical depletion of ozone later in spring is not established.

It is also worth noting that the $2011 \mathrm{BrO}$ vortex averages (Fig. 5) show a "thinning effect", nicely corresponding to that in ozone between 21 and 30 January 2011. The "thinning" also extends well into the stratosphere, close to the $575 \mathrm{~K}$ isentropic surface. Relative to values before and after the event, approximately $45 \%$ less $\mathrm{BrO}$ is observed at $450 \mathrm{~K}$ and $\sim 25 \%$ less at $550 \mathrm{~K}$. As a result of the concentricity of the vortex during the OMH-like situation, the limb observations represent well the mean state of the measured trace constituents inside the vortex and are relatively insensitive to mixing processes across the polar vortex boundary. As a consequence, the vertically resolved $\mathrm{BrO}$ mixing-ratio time series provides further evidence that these transient reductions in the observed mixing ratios during the second half of January 2011 are caused by tropopause elevations, affecting all trace constituents in the respective region.

\section{Conclusions}

Data products retrieved from measurements made by the instruments SCIAMACHY and GOME/GOME-2 have been used in this study to investigate the state of ozone in Arctic winters from 2002/2003 to 2010/2011. As an example of the large year-to-year variation in Arctic ozone, the different behaviours of $\mathrm{O}_{3}$ in the consecutive boreal winter-spring periods in 2009/2010 and 2010/2011 have been investigated in detail. Height-resolved time series of vortex-averaged $\mathrm{O}_{3}$, $\mathrm{BrO}, \mathrm{NO}_{2}$ from SCIAMACHY limb-scattering and solaroccultation measurements were analysed. From limb-scatter observations chemically induced ozone losses are determined on a daily basis by accounting for the model-estimated diabatic ozone descent. SCIAMACHY observations of PSC from the limb viewing geometry are used together with nadir OClO slant columns and $\mathrm{NO}_{2}$ vertical columns at $90^{\circ} \mathrm{SZA}$ to investigate ozone depleting processes. Our understanding and ability to accurately simulate polar ozone depleting processes was tested by comparing measurements with the results from a three-dimensional isentropic chemistry transport model for the years 2010 and 2011.

From limb measurements, we infer an ozone loss of more than $70 \%$ below the $550 \mathrm{~K}$ isentropic surface in spring 2011, which corresponds well with estimates of previous studies (e.g. Manney et al., 2011; Sinnhuber et al., 2011; Arnone et al., 2012; Kuttippurath et al., 2012). In contrast, in spring 2010 , when the vortex was much warmer and weaker than in 2011, chemically induced ozone loss amounted to only about $20 \%$. Differences in the vortex dynamics, coupled with the chemical processing of $\mathrm{O}_{3}$ between the two winters and springs account for differences in the ozone time series above the $550 \mathrm{~K}$ isentropic surface. In 2010 , the variability in the $\mathrm{O}_{3}$ profiles is large in these upper layers and about twice as much ozone is depleted via $\mathrm{NO}_{\mathrm{x}}$ photochemistry than via 
heterogeneous processing on PSC below $550 \mathrm{~K}$. CTM simulated ozone losses are consistent with observations from SCIAMACHY and other instruments in both years. In particular the day-to-day variability of polar cap ozone and the large ozone loss from heterogenous processes in spring 2011 are represented well. Differences between the modelled and the observed ozone losses arise from differences in the data sampling, and from uncertainties in modelling the halogen catalytic cycles destroying the ozone. On the other hand, limitations of the assumptions made in the vortex-averaging method, used to infer ozone loss from limb measurements, may also explain some of the differences.

The $\mathrm{O}_{3}$ vortex-average mixing ratios indicate another, previously unreported, low ozone period during winter 2011 which occurred prior to the large chemical destruction of $\mathrm{O}_{3}$. For about 10 days commencing 20 January 2011, column ozone over the Arctic decreased rapidly by more than 70 DU. Limb measurements show that below the $500 \mathrm{~K}$ isentrope ozone was reduced by up to $60 \%$ to values as low as 1.5 ppmv. It turns out that a superposition of two independently evolving synoptic tropopause elevations over the Asian continent lowered the stratospheric ozone column by adiabatically lifting isentropes in the stratosphere. This behaviour is commonly referred to as an ozone mini-hole. This involves a horizontal "redistribution" of ozone from the column (horizontal divergence) which is more pronounced in the ozone profiles from SCIAMACHY limb measurements than in our CTM simulation. Due to the relatively coarse horizontal resolution the model does not adequately resolve this meridional dispersion of ozone out of the elevated column. Together with differences in the sampling of the data in the illuminated part of the vortex, this leads to a different temporal development of the vortex-averaged time series in the model. The induced adiabatic cooling of the stratosphere during this period enhanced PSC formation. But chlorine activation has not been intensified markedly, according to our OClO measurements. It remains speculative whether the event had a direct impact on the severe ozone loss later in spring, even though the dynamically depleted ozone area was almost as large as a chemically induced ozone hole, that is at least a third larger than the area covered by previously studied ozone mini-holes.

SCIAMACHY observations demonstrate that the time behaviour of the vortex $\mathrm{BrO}$ abundance during the course of winter 2011 correlates well with the increase in the polar $\mathrm{NO}_{2}$ abundance, as expected. This relationship is less pronounced in the limb observations than in the solaroccultation data set. As a result of the sun-sychronus orbit of Envisat, SCIAMACHY solar-occultation measurements are confined to latitudes between 49 and $69^{\circ} \mathrm{N}$, hence, the geographic sampling within the vortex is rather sparse compared to limb measurements. The apparent difference in the morphologies of the $\mathrm{BrO}$ time series is explained by lateral mixing processes along the polar vortex boundary. This is because the partitioning into summertime bromine reservoirs is known to start earlier in spring in this region than further poleward. The CTM reproduces well the seasonal cycle in stratospheric $\mathrm{BrO}$, compared to other studies (e.g. Theys et al., 2009), but the vortex abundances of $\mathrm{BrO}$ and $\mathrm{NO}_{2}$ are biased low compared to SCIAMACHY limb and solaroccultation measurements. The origin of this behaviour has not been fully understood.

In agreement with previous studies using other satellite instruments, SCIAMACHY observations show that the season of PSC formation was longer in 2011 over the Arctic than previously reported. Similarly, chlorine activation appears to have been larger than seen in any other previous Arctic spring measured by SCIAMACHY.

In this study we described correlative observations of the compositional state of the Arctic stratosphere during winterspring 2010/2011, when the largest ozone loss has been reported. We compared this Arctic situation with that in 2009/2010, which is an example of a weak Arctic vortex exhibiting higher ozone levels. The understanding of the chemical composition of the Arctic stratosphere improves our knowledge about the processes determining the observed large intrinsic variability of Arctic ozone levels. This is of concern when assessing the predicability of future ozone and accompanied polar winter extremes because it is suspected that global climate change impacts stratospheric conditions. Although in general our CTM has been able to provide reasonable agreement with the observations, there are several detailed issues to be resolved in future studies. Finally, the observation of a large OMH-like situation preceding severe ozone loss over the Arctic is raising further questions, in particular with respect to their relevance for the efficient ozonedestroying processes in the Arctic stratosphere, should these large OMH-like situations more often appear and intensify in a future warming climate.

Acknowledgements. This work was funded in part by the European commission under the project Stratospheric ozone: Halogen Impacts in a Varying Atmosphere (SHIVA; FP7-ENV-2007-1226224), the DFG Research Unit 1095 Stratospheric Change and its Role for Climate Prediction (SHARP), the German Federal Ministry of Education and Research (BMBF) under the project ROSA (funding reference code 01LG1212A), and by the State and University of Bremen. C. von Savigny was partly supported by the University of Greifswald. Part of this work was supported by the project DACCS as part of the DFG priority program CAWSES. The authors thank the anonymous reviewers for their helpful comments in improving the manuscript. We also thank several colleagues for suggestions and comments, in particular Hans F. Graf and Björn-Martin Sinnhuber, as well as Felix Ebojie, Katja Weigel, Stefan Noël, Claus Gebhardt and Emmanouil Proestakis. We also like to thank Gregor Kiesewetter, Peter Voelger, and Michael C. Pitts for providing access to additional data.

Edited by: P. Monks 


\section{References}

Adams, C., Strong, K., Zhao, X., Bassford, M. R., Chipperfield, M. P., Daffer, W., Drummond, J. R., Farahani, E. E., Feng, W., Fraser, A., Goutail, F., Manney, G., McLinden, C. A., Pazmino, A., Rex, M., and Walker, K. A.: Severe 2011 ozone depletion assessed with 11 years of ozone, $\mathrm{NO}_{2}$, and OClO measurements at $80^{\circ} \mathrm{N}$, Geophys. Res. Lett., 39, L05806, doi:10.1029/2011GL050478, 2012.

Arnone, E., Castelli, E., Papandrea, E., Carlotti, M., and Dinelli, B. M.: Extreme ozone depletion in the 2010-2011 Arctic winter stratosphere as observed by MIPAS/ENVISAT using a 2D tomographic approach, Atmos. Chem. Phys., 12, 9149-9165, doi:10.5194/acp-12-9149-2012, 2012.

Aschmann, J., Sinnhuber, B.-M., Atlas, E. L., and Schauffler, S. M.: Modeling the transport of very short-lived substances into the tropical upper troposphere and lower stratosphere, Atmos. Chem. Phys., 9, 9237-9247, doi:10.5194/acp-9-9237-2009, 2009.

Aschmann, J., Sinnhuber, B.-M., Chipperfield, M. P., and Hossaini, R.: Impact of deep convection and dehydration on bromine loading in the upper troposphere and lower stratosphere, Atmos. Chem. Phys., 11, 2671-2687, doi:10.5194/acp-11-2671-2011, 2011.

Balis, D., Isaksen, I. S. A., Zerefos, C., Zyrichidou, I., Eleftheratos, K., Tourpali, K., Bojkov, R., Rognerud, B., Stordal, F., Søvde, O. A., and Orsolini, Y.: Observed and modelled record ozone decline over the Arctic during winter/spring 2011, Geophys. Res. Lett., 38, L23801, doi:10.1029/2011GL049259, 2011.

Bauer, R., Rozanov, A., McLinden, C. A., Gordley, L. L., Lotz, W., Russell III, J. M., Walker, K. A., Zawodny, J. M., LadstätterWeißenmayer, A., Bovensmann, H., and Burrows, J. P.: Validation of SCIAMACHY limb $\mathrm{NO}_{2}$ profiles using solar occultation measurements, Atmos. Meas. Tech., 5, 1059-1084, doi:10.5194/amt-5-1059-2012, 2012.

Bovensmann, H., Burrows, J. P., Buchwitz, M., Frerick, J., Noël, S., Rozanov, V. V., Chance, K. V., and Goede, A. P. H.: Sciamachy: Mission objectives and measurement modes, J. Atmos. Sci., 56, 127-150, 1999.

Bracher, A., Lamsal, L. N., Weber, M., Bramstedt, K., ColdeweyEgbers, M., and Burrows, J. P.: Global satellite validation of SCIAMACHY O 3 columns with GOME WFDOAS, Atmos. Chem. Phys., 5, 2357-2368, doi:10.5194/acp-5-2357-2005, 2005.

Bramstedt, K., Amekudzi, L., Bracher, A., Rozanov, A., Bovensmann, H., and Burrows, J. P.: SCIAMACHY solar occultation: Ozone and $\mathrm{NO}_{2}$ profiles from 2002-2006, in: Proceeding of the ERS-Envisat Symposium, ESA-SP 636, ESA Publications Division, Montreux, 2007.

Bramstedt, K., Noël, S., Bovensmann, H., Gottwald, M., and Burrows, J. P.: Precise pointing knowledge for SCIAMACHY solar occultation measurements, Atmos. Meas. Tech., 5, 2867-2880, doi:10.5194/amt-5-2867-2012, 2012.

Burrows, J. P., Hölzle, E., Goede, A., Visser, H., and Fricke, W.: SCIAMACHY - Scanning Imaging Absorption Spectrometer for Atmospheric Chartography, Acta Astronaut., 35, 445-451, 1995.
Burrows, J., Weber, M., Buchwitz, M., Rozanov, V. V., LadstätterWeißenmayer, A., Richter, A., DeBeek, R., Hoogen, R., Bramstedt, K., and Eichmann, K.: The Global Ozone Monitoring Experiment (GOME): Mission Concept and First Scientific Results, J. Atmos. Sci., 56, 151-175, doi:10.1175/15200469(1999)056<0151:TGOMEG>2.0.CO;2, 1999.

Burrows, J., Platt, U., and Borrell, P.: The Remote Sensing of Tropospheric Composition from Space, Physics of Earth and Space Environments, Springer, 2011.

Callies, J., Corpaccioli, E., Eisinger, M., Hahne, A., and Lefebvre, A.: GOME-2 - METOP's second-generation sensor for operational ozone monitoring, ESA Bull., 102, 28-36, 2000.

Chipperfield, M. P.: Multiannual simulations with a threedimensional chemical transport model, J. Geophys. Res., 104, 1781-1805, 1999.

Coldewey-Egbers, M., Weber, M., Lamsal, L. N., de Beek, R., Buchwitz, M., and Burrows, J. P.: Total ozone retrieval from GOME UV spectral data using the weighting function DOAS approach, Atmos. Chem. Phys., 5, 5015-5025, doi:10.5194/acp5-5015-2005, 2005.

Dhomse, S., Weber, M., Wohltmann, I., Rex, M., and Burrows, J. P.: On the possible causes of recent increases in northern hemispheric total ozone from a statistical analysis of satellite data from 1979 to 2003, Atmos. Chem. Phys., 6, 1165-1180, doi:10.5194/acp-6-1165-2006, 2006.

Doicu, A., Hilgers, S., von Bargen, A., Rozanov, A., Eichmann, K.-U., von Savigny, C., and Burrows, J. P.: Information Operator Approach and iterative regularization methods for atmospheric remote sensing, J. Quant. Spectrosc. Ra., 103, 340-350, doi:10.1016/j.jqsrt.2006.05.002, 2007.

Dörnbrack, A., Pitts, M. C., Poole, L. R., Orsolini, Y. J., Nishii, K. and Nakamura, H.: The 2009-2010 Arctic stratospheric winter general evolution, mountain waves and predictability of an operational weather forecast model, Atmos. Chem. Phys., 12, 3659 3675, doi:10.5194/acp-12-3659-2012, 2012.

Eichmann, K.-U., Weber, M., Bramstedt, K., and Burrows, J. P.: Ozone depletion in the NH winter/spring 1999/2000 as measured by GOME-ERS2, J. Geophys. Res., 107, 8280, doi:10.1029/2001JD001148, 2002.

Fortuin, P. J. F. and Kelder, H.: An ozone climatology based on ozonesonde and satellite measurements, J. Geophys. Res., 103, 31709-31734, doi:10.1029/1998JD200008, 1998.

Frieler, K., Rex, M., Salawitch, R. J., Canty, T., Streibel, M., Stimpfle, R. M., Pfeilsticker, K., Dorf, M., Weisenstein, D. K., and Godin-Beekmann, S.: Toward a better quantitative understanding of polar stratospheric ozone loss, Geophys. Res. Lett., 33, L10812, doi:10.1029/2005GL025466, 2006.

Fusco, A. and Salby, M.: Interannual variations of total ozone and their relationship to variations of planetary wave activity, J. Climate, 12, 1619-1629, 1999.

Grooß, J.-U., Müller, R., Konopka, P., Steinhorst, H.-M., Engel, A., Möbius, T., and Volk, C. M.: The impact of transport across the polar vortex edge on Match ozone loss estimates, Atmos. Chem. Phys., 8, 565-578, doi:10.5194/acp-8-565-2008, 2008.

Han, J., Yamazaki, K., and Niwano, M.: The winter ozone minimum over the subtropical northwestern Pacific, J. Meteorol. Soc. Jpn., 81, 57-67, doi:10.2151/jmsj.83.57, 2005. 
Hartmann, D. L., Wallace, J. M., Limpasuvan, V., Thompson, D. W. J., and Holton, J. R.: Can ozone depletion and global warming interact to produce rapid climate change?, Proc. Natl. Acad. Sci., 97, 1412-1417, 2000.

Hendrick, F., Van Roozendael, M., Kylling, A., Petritoli, A., Rozanov, A., Sanghavi, S., Schofield, R., von Friedeburg, C., Wagner, T., Wittrock, F., Fonteyn, D., and De Mazière, M.: Intercomparison exercise between different radiative transfer models used for the interpretation of ground-based zenith-sky and multi-axis DOAS observations, Atmos. Chem. Phys., 6, 93-108, doi:10.5194/acp-6-93-2006, 2006.

Hoogen, R., Rozanov, V. V., and Burrows, J. P.: Ozone profiles from GOME satellite data: Algorithm description and first validation, J. Geophys. Res., 104, 8263-8280, doi:10.1029/1998JD100093, 1999.

Hurwitz, M., Newman, P. A., and Garfinkel, C. I.: The Arctic vortex in March 2011: a dynamical perspective, Atmos. Chem. Phys., 11, 11447-11453, doi:10.5194/acp-11-11447-2011, 2011.

James, P. M.: An interhemispheric comparison of ozone mini-hole climatologies, Geophys. Res. Lett., 25, 301-304, 1998.

Khosrawi, F., Urban, J., Pitts, M. C., Voelger, P., Achtert, P., Kaphlanov, M., Santee, M. L., Manney, G. L., Murtagh, D., and Fricke, K.-H.: Denitrification and polar stratospheric cloud formation during the Arctic winter 2009/2010, Atmos. Chem. Phys., 11, 8471-8487, doi:10.5194/acp-11-8471-2011, 2011.

Khosrawi, F., Urban, J., Pitts, M. C., Voelger, P., Achtert, P., Santee, M. L., Manney, G. L., and Murtagh, D.: Denitrification and polar stratospheric cloud formation during the Arctic winter 2009/2010 and 2010/2011 in comparison, Proceedings of the ESA Atmospheric Science Conference 18-22 June 2012, Bruges, Belgium, pp. ESA-SP-708, Eur. Space Agency Spec. Publ., November 2012, ISBN/ISSN:978-92-9092-272-8, 2012.

Kiesewetter, G., Sinnhuber, B.-M., Vountas, M., Weber, M., and Burrows, J. P.: A long-term stratospheric ozone data set from assimilation of satellite observations: Highlatitude ozone anomalies, J. Geophys. Res., 115, D10307, doi:10.1029/2009JD013362, 2010a.

Kiesewetter, G., Sinnhuber, B.-M., Weber, M., and Burrows, J. P.: Attribution of stratospheric ozone trends to chemistry and transport: a modelling study, Atmos. Chem. Phys., 12073-12089, doi:10.5194/acp-10-12073-2010, 2010 b.

Koch, G., Wernli, H., Schwierz, C., Staehelin, J., and Peter, T.: A composite study on the structure and formation of ozone miniholes and minihighs over central Europe, Geophys. Res. Lett., 32, L12810, doi:10.1029/2004GL022062, 2005.

Konopka, P., Engel, A., Funke, B., Müller, R., Grooß, J.U., Günther, G., Wetter, T., Stiller, G., von Clarmann, T., Glatthor, N., Oelhaf, H., Wetzel, G., López-Puertas, M., Pirre, M., Huret, N., and Riese, M.: Ozone loss driven by nitrogen oxides and triggered by stratospheric warmings can outweigh the effect of halogens, J. Geophys. Res., 112, D5105, doi:10.1029/2006JD007064, 2007.

Kozlov, V.: Design of experiments related to the inverse of mathematical physics, in: Mathematical Theory of Experiment Design (in Russian), edited by: Ermakov, C. M., 216-246, Nauka, Moscow, 1983.
Krzyścin, J. W.: Long-term changes in ozone mini-hole event frequency over the northern hemisphere derived from ground-based measurements, Int. J. Climatol., 22, 1425-1439, doi:10.1002/joc.812, 2002.

Kuttippurath, J. and Nikulin, G.: A comparative study of the major sudden stratospheric warmings in the Arctic winters 2003/2004-2009/2010, Atmos. Chem. Phys., 12, 8115-8129, doi:10.5194/acp-12-8115-2012, 2012.

Kuttippurath, J., Goutail, F., Pommereau, J.-P., Lefèvre, F., Roscoe, H. K., Pazmiño, A., Feng, W., Chipperfield, M. P., and GodinBeekmann, S.: Estimation of Antarctic ozone loss from groundbased total column measurements, Atmos. Chem. Phys., 10, 6569-6581, doi:10.5194/acp-10-6569-2010, 2010.

Kuttippurath, J., Godin-Beekmann, S., Lefèvre, F., Nikulin, G., Santee, M. L., and Froidevaux, L.: Record-breaking ozone loss in the Arctic winter 2010/2011: comparison with 1996/1997, Atmos. Chem. Phys., 12, 7073-7085, doi:10.5194/acp-12-70732012, 2012.

Lindenmaier, R., Strong, K., Batchelor, R. L., Chipperfield, M. P., Daffer, W. H., Drummond, J. R., Duck, T. J., Fast, H., Feng, W., Fogal, P. F., Kolonjari, F., Manney, G. L., Manson, A., Meek, C., Mittermeier, R. L., Nott, G. J., Perro, C., and Walker, K. A.: Unusually low ozone, $\mathrm{HCl}$, and $\mathrm{HNO}_{3}$ column measurements at Eureka, Canada during winter/spring 2011, Atmos. Chem. Phys., 12, 3821-3835, doi:10.5194/acp-12-3821-2012, 2012.

Liu, C., Liu, Y., Cai, Z., Gao, S., Lü, D., and Kyrölä, E.: A MaddenJulian Oscillation-triggered record ozone minimum over the Tibetan Plateau in December 2003 and its association with stratospheric "low-ozone pockets", Geophys. Res. Lett., 36, L15830, doi:10.1029/2009GL039025, 2009.

Mäder, J. A., Staehelin, J., Peter, T., Brunner, D., Rieder, H. E., and Stahel, W. A.: Evidence for the effectiveness of the Montreal Protocol to protect the ozone layer, Atmos. Chem. Phys., 10, 19005-19029, doi:10.5194/acp-10-12161-2010, 2010.

Manney, G. L., Zurek, R. W., O’Neil, A., and Swinbank, R.: On the motions of air through the stratosphere polar vortex, J. Atmos. Sci., 52, 2973-2994, 1994.

Manney, G. L., Daffer, W. H., Strawbridge, K. B., Walker, K. A., Boone, C. D., Bernath, P. F., Kerzenmacher, T., Schwartz, M. J., Strong, K., Sica, R. J., Krüger, K., Pumphrey, H. C., Lambert, A., Santee, M. L., Livesey, N. J., Remsberg, E. E., Mlynczak, M. G., and Russell III, J. R.: The high Arctic in extreme winters: vortex, temperature, and MLS and ACE-FTS trace gas evolution, Atmos. Chem. Phys., 8, 505-522, doi:10.5194/acp-8-505-2008, 2008.

Manney, G. L., Santee, M. L., Rex, M., Livsey, N. J., Pitts, M. C., Veefkind, P., Nash, E. R., Wohltmann, I., Lehmann, R., Froidevaux, L., Poole, L. R., Schoeberl, M. R., Haffner, D. P., Davies, J., Dorokhov, V., Gernandt, H., Johnson, B., Kivi, R., Kyrö, E., Larsen, N., Levelt, P. F., Makshtas, A., McElroy, C. T., Nakajima, H., Parrondo, M. C., Tarasick, D. W., von der Gathen, P., Walker, K. A., and Zinoviev, N. S.: Unprecedented Arctic ozone loss in 2011, Nature, 478, 469-475, doi:10.1038/nature10556, 2011.

McLinden, C. A., Olsen, S. C., Hannegan, B., Wild, O., Prather, M. J., and Sundet, J.: Stratospheric ozone in 3-D models: A simple chemistry and the cross-tropopause flux., J. Geophys. Res., 105, 14653-14665, doi:10.1029/2000JD900124, 2000. 
McLinden, C. A., Haley, C. S., Lloyd, N. D., Hendrick, F., Rozanov, A., Sinnhuber, B., Goutail, F., Degenstein, D. A., Llewellyn, E. J., Sioris, C. E., Van Roozendael, M., Pommereau, J. P., Lotz, W., and Burrows, J. P.: Odin/OSIRIS observations of stratospheric BrO: Retrieval methodology, climatology, and inferred Bry, J. Geophys. Res., 115, D15308, doi:10.1029/2009JD012488, 2010.

Meyer, J., Bracher, A., Rozanov, A., Schlesier, A. C., Bovensmann, H., and Burrows, J. P.: Solar occultation with SCIAMACHY: algorithm description and first validation, Atmos. Chem. Phys., 5, 1589-1604, doi:10.5194/acp-5-1589-2005, 2005.

Mieruch, S., Weber, M., von Savigny, C., Rozanov, A., Bovensmann, H., Burrows, J. P., Bernath, P. F., Boone, C. D., Froidevaux, L., Gordley, L. L., Mlynczak, M. G., Russell III, J. M., Thomason, L. W., Walker, K. A., and Zawodny, J. M.: Global and long-term comparison of SCIAMACHY limb ozone profiles with correlative satellite data (2002-2008), Atmos. Meas. Tech., 5, 771-788, doi:10.5194/amt-5-771-2012, 2012.

Mitchell, D. M., Gray, L. J., and Charlton-Perez, A. J.: The structure and evolution of the stratospheric vortex in response to natural forcings, J. Geophys. Res., 116, D15110, doi:10.1029/2011JD015788, 2011.

Nash, E. R., Newman, P. A., Rosenfield, J. E., and Schoeberl, M. R.: An objective determination of the polar vortex using Ertels potential vorticity, J. Geophys. Res., 101, 9471-9478, 1996.

Newman, P. A., Lait, L. R., and Schoeberl, M. R.: The morphology and meteorology of southern hemisphere spring total ozone miniholes, Geophys. Res. Lett., 15, 923-926, 1988.

Oetjen, H., Wittrock, F., Richter, A., Chipperfield, M. P., Medeke, T., Sheode, N., Sinnhuber, B.-M., Sinnhuber, M., and Burrows, J. P.: Evaluation of stratospheric chlorine chemistry for the Arctic spring 2005 using modelled and measured OClO column densities, Atmos. Chem. Phys., 11, 689-703, doi:10.5194/acp-11-6892011, 2011.

Orsolini, Y. J., Stephenson, D. B., and Doblas-Reyes, F. J.: Storm track signature in total ozone during northern hemisphere winter, Geophys. Res. Lett., 25, 2413, doi:10.1029/98GL01852, 1998.

Osterman, G. B., Salawitch, R. J., Sen, B., Toon, G. C., Stachnik, R. A., Pickett, H. M., Margitan, J. J., Blavier, J., and Peterson, D. B.: Balloonborne measurements of stratospheric radicals and their precursors: Implications for the production and loss of ozone, Geophys. Res. Lett., 24, 1107-1110, doi:10.1029/97GL00921, 1997.

Platt, U.: Differential optical absorption spectroscopy (DOAS), in: Air Monitoring by Spectroscopic Techniques, edited by: Sigrist, M. W., Chemical Analysis Series, John Wiley, New York, 127, 27-84, 1994.

Pommereau, J.-P., Goutail, F., Lefèvre, F., Pazmino, A., Adams, C., Dorokhov, V., Eriksen, P., Kivi, R., Stebel, K., Zhao, X., and van Roozendael, M.: Why unprecedented ozone loss in the Arctic in 2011 ? Is it related to climate change?, Atmos. Chem. Phys., 13, 5299-5308, doi:10.5194/acp-13-5299-2013, 2013.

Reed, R.: On the role of vertical motions in ozone-weather relationships, J. Meteorol., 7, 263-267, 1950.

Rex, M., Salawitch, R. J., von der Gathen, P., Harris, N. R. P., Chipperfield, M. P., and Naujokat, B.: Arctic ozone loss and climate change, Geophys. Res. Lett., 31, L04116, doi:10.1029/2003GL018844, 2004.
Rex, M., Salawitch, R. J., Deckelmann, H., von der Gathen, P., Harris, N. R. P., Chipperfield, M. P., Naujokat, B., Reimer, E., Allaart, M., Andersen, S. B., Bevilacqua, R., Braathen, G. O., Claude, H., Davies, J., De Backer, H., Dier, H., Dorokhov, V., Fast, H., Gerding, M., Godin-Beekmann, S., Hoppel, K., Johnson, B., Kyrö, E., Litynska, Z., Moore, D., Nakane, H., Parrondo, M. C., Risley, A. D., Skrivankova, P., Stübi, R., Viatte, P., Yushkov, V., and Zerefos, C.: Arctic winter 2005: Implications for stratospheric ozone loss and climate change, Geophys. Res. Lett., 33, L23808, doi:10.1029/2006GL026731, 2006.

Richter, A., Eisinger, M., Ladstätter-Weißenmayer, A., and Burrows, J. P.: DOAS zenith sky observations. 2. Seasonal variation of BrO over Bremen $\left(53^{\circ} \mathrm{N}\right)$ 1994-1995, J. Atmos. Chem., 32, 83-99, 1999.

Richter, A., Wittrock, F., Weber, M., Beirle, S., Kühl, S., Platt, U., Wagner, T., Wilms-Grabe, W., and Burrows, J. P.: GOME observations of stratospheric trace gas distributions during the splitting vortex event in the Antarctic winter 2002 Part I: Measurements, J. Atmos. Sci., 62, 778-785, 2005.

Rodgers, C. D.: Inverse methods for atmospheric sounding: Theory and practice, World Scientific, 2000.

Rohen, G., von Savigny, C., Kaiser, J. W., Llewellyn, E. J., Froidevaux, L., Lopez-Puertas, M., Steck, T., Palm, M., Winkler, H., Sinnhuber, M., Bovensmann, H., and Burrows, J. P.: Ozone profile retrieval from limb scatter measurements in the HARTLEY bands: further retrieval details and profile comparisons., Atmos. Chem. Phys., 8, 2509-2517, doi:10.5194/acp-8-2509-2008, 2008.

Rosenfield, J. E., Newman, P. E., and Schoeberl, M. R.: Computations of diabatic descent in the stratospheric polar vortex, J. Geophys. Res., 99, 16677-16689, doi:10.1029/94JD01156, 1994.

Rozanov, A., Bovensmann, H., Bracher, A., Hrechanyy, S., Rozanov, V., Sinnhuber, M., Stroh, F., and Burrows, J.: $\mathrm{NO}_{2}$ and $\mathrm{BrO}$ vertical profile retrieval from SCIAMACHY limb measurements: Sensitivity studies, Adv. Space Res., 36, 846-854, doi:10.1016/j.asr.2005.03.013, 2005.

Rozanov, A., Kühl, S., Doicu, A., McLinden, C., Pukīte, J., Bovensmann, H., Burrows, J. P., Deutschmann, T., Dorf, M., Goutail, F., Grunow, K., Hendrick, F., von Hobe, M., Hrechanyy, S., Lichtenberg, G., Pfeilsticker, K., Pommereau, J. P., Van Roozendael, M., Stroh, F., and Wagner, T.: BrO vertical distributions from SCIAMACHY limb measurements: comparison of algorithms and retrieval results, Atmos. Meas. Tech., 4, 1319-1359, doi:10.5194/amt-4-1319-2011, 2011a.

Rozanov, A., Weigel, K., Bovensmann, H., Dhomse, S., Eichmann, K.-U., Kivi, R., Rozanov, V. V., Vömel, H., Weber, M., and Burrows, J. P.: Retrieval of water vapor vertical distributions in the upper troposphere and the lower stratosphere from SCIAMACHY limb measurements, Atmos. Meas. Tech., 4, 933-954, doi:10.5194/amt-4-933-2011, $2011 \mathrm{~b}$.

Salawitch, R. J., Weisenstein, D. K., Kovalenko, L. J., Sioris, C. E., Wennberg, P. O., Chance, K., Ko, M. K. W., and McLinden, C. A.: Sensitivity of ozone to bromine in the lower stratosphere, Geophys. Res. Lett., 32, L05811, doi:10.1029/2004GL021504, 2005.

Salby, M., Titova, E., and Deschamps, L.: Rebound of Antarctic ozone, Geophys. Res. Lett., 38, L09702, doi:10.1029/2011GL047266, 2011. 
Sander, S., Friedl, R., Ravishankara, A., Golden, D., Kolb, C., Kurylo, M., Huie, R., Orkin, V., Molina, M., Moortgat, G., and Finlayson-Pitts, B.: Chemical Kinetics and Photochemical Data for Use in Atmospheric Studies, JPL Publication 06-2, Evaluation No 15, NASA Jet Propulsion Laboratory, California Institute of Technology, Pasadena, California, 2006.

Shine, K. P.: The middle atmosphere in the absence of dynamic heat fluxes, Q. J. Roy. Meteor. Soc., 113, 603-633, 1987.

Singleton, C., Randall, C., Harvey, V., Chipperfield, M., Feng, W., Manney, G., Froidevaux, L., Boone, C., Bernath, P., Walker, K., McElroy, C., and Hoppel, K.: Quantifying Arctic ozone loss during the 2004-2005 winter using satellite observations and a chemical transport model, J. Geophys. Res., 112, D07304, doi:10.1029/2006JD007463, 2007.

Singleton, C. S., Randall, C. E., Chipperfield, M. P., Davies, S., Feng, W., Bevilacqua, R. M., Hoppel, K. W., Fromm, M. D., Manney, G. L., and Harvey, V. L.: 2002-2003 Arctic ozone loss deduced from POAM III satellite observations and the SLIMCAT chemical transport model, Atmos. Chem. Phys., 5, 597609, doi:10.5194/acp-5-597-2005, 2005.

Sinnhuber, B.-M., Arlander, D. W., Bovensmann, H., Burrows, J. P., Chipperfield, M. P., Enell, C.-F., Frieß, U., Hendrick, F., Johnston, P. V., Jones, R. L., Kreher, K., Mohamed-Tahrin, N., Müller, R., Pfeilsticker, K., Platt, U., Pommereau, J.-P., Pundt, I., Richter, A., South, A. M., Tørnkvist, K. K., Van Roozendael, M., Wagner, T., and Wittrock, F.: Comparison of measurements and model calculations of stratospheric bromine monoxide, J. Geophys. Res., 107, 4398, doi:10.1029/2001JD000940, 2002.

Sinnhuber, B.-M., Weber, M., Amankwah, A., and Burrows, J. P.: Total ozone during the unusual Antarctic winter of 2002, Geophys. Res. Lett., 30, 1580, doi:10.1029/2002GL016798, 2003.

Sinnhuber, B.-M., Stiller, G., Ruhnke, R., von Clarmann, T., Kellmann, S., and Aschmann, J.: Arctic winter 2010/2011 at the brink of an ozone hole, Geophys. Res. Lett., 38, L24814, doi:10.1029/2011GL049784, 2011.

Sonkaew, T., Rozanov, V. V., von Savigny, C., Rozanov, A., Bovensmann, H., and Burrows, J. P.: Cloud sensitivity studies for stratospheric and lower mesospheric ozone profile retrievals from measurements of limb-scattered solar radiation, Atmos. Meas. Tech., 2, 653-678, doi:10.5194/amt-2-653-2009, 2009.

Sonkaew, T., von Savigny, C., Eichmann, K.-U., Weber, M., Rozanov, A., Bovensmann, H., Burrows, J. P., and Grooß, J. U.: Chemical ozone losses in Arctic and Antarctic polar winter/spring season derived from SCIAMACHY limb measurements 2002-2009, Atmos. Chem. Phys., 13, 1809-1835, doi:10.5194/acp-13-1809-2013, 2013.

Steinbrecht, W., Köhler, U., Claude, H., Weber, M., Burrows, J. P., and van der A, R. J.: Very high ozone columns at northern mid-latitudes in 2010, Geophys. Res. Lett., 38, L06803, doi:10.1029/2010GL046634, 2011.

Stolarski, R. S. and Frith, S. M.: Search for evidence of trend slowdown in the long-term TOMS/SBUV total ozone data record: the importance of instrument drift uncertainty, Atmos. Chem. Phys., 6, 4057-4065, doi:10.5194/acp-6-4057-2006, 2006.

Strahan, S. E., Douglass, A. R., and Newman, P. A.: The contributions of chemistry and transport to low arctic ozone in March 2011 derived from Aura MLS observations, J. Geophys. Res., 118, 1563-1576, doi:10.1002/jgrd.50181, 2013.
Theys, N., Van Roozendael, M., Errera, Q., Hendrick, F., Daerden, F., Chabrillat, S., Dorf, M., Pfeilsticker, K., Rozanov, A., Lotz, W., Burrows, J., Lambert, J.-C., Goutail, F., Roscoe, H., and De Maziere, M.: A global stratospheric bromine monoxide climatology based on the BASCOE chemical transport model, Atmos. Chem. Phys., 9, 831-848, doi:10.5194/acp-9-831-2009, 2009.

Theys, N., Van Roozendael, M., Hendrick, F., Yang, X., De Smedt, I., Richter, A., Begoin, M., Errera, Q., Johnston, P. V., Kreher, K., and De Mazière, M.: Global observations of tropospheric BrO columns using GOME-2 satellite data, Atmos. Chem. Phys., 11, 1791-1811, doi:10.5194/acp-11-1791-2011, 2011.

von Hobe, M., Bekki, S., Borrmann, S., Cairo, F., D’Amato, F., Di Donfrancesco, G., Dörnbrack, A., Ebersoldt, A., Ebert, M., Emde, C., Engel, I., Ern, M., Frey, W., Genco, S., Griessbach, S., Grooß, J.-U., Gulde, T., Günther, G., Hösen, E., Hoffmann, L., Homonnai, V., Hoyle, C. R., Isaksen, I. S. A., Jackson, D. R., Jánosi, I. M., Jones, R. L., Kandler, K., Kalicinsky, C., Keil, A., Khaykin, S. M., Khosrawi, F., Kivi, R., Kuttippurath, J., Laube, J. C., Lefèvre, F., Lehmann, R., Ludmann, S., Luo, B. P., Marchand, M., Meyer, J., Mitev, V., Molleker, S., Müller, R., Oelhaf, H., Olschewski, F., Orsolini, Y., Peter, T., Pfeilsticker, K., Piesch, C., Pitts, M. C., Poole, L. R., Pope, F. D., Ravegnani, F., Rex, M., Riese, M., Röckmann, T., Rognerud, B., Roiger, A., Rolf, C., Santee, M. L., Scheibe, M., Schiller, C., Schlager, H., Siciliani de Cumis, M., Sitnikov, N., Søvde, O. A., Spang, R., Spelten, N., Stordal, F., Sumińska-Ebersoldt, O., Ulanovski, A., Ungermann, J., Viciani, S., Volk, C. M., vom Scheidt, M., von der Gathen, P., Walker, K., Wegner, T., Weigel, R., Weinbruch, S., Wetzel, G., Wienhold, F. G., Wohltmann, I., Woiwode, W., Young, I. A. K., Yushkov, V., Zobrist, B., and Stroh, F.: Reconciliation of essential process parameters for an enhanced predictability of Arctic stratospheric ozone loss and its climate interactions (RECONCILE): activities and results, Atmos. Chem. Phys., 13, 92339268, doi:10.5194/acp-13-9233-2013, 2013.

von Savigny, C., Ulasi, E. P., Eichmann, K.-U., Bovensmann, H., and Burrows, J. P.: Detection and mapping of polar stratospheric clouds using limb scattering observations, Atmos. Chem. Phys., 5, 3071-3079, doi:10.5194/acp-5-3071-2005, 2005a.

von Savigny, C., Rozanov, A., Bovensmann, H., Eichmann, K.-U., Noël, S., Rozanov, V. V., Sinnhuber, B.-M., Weber, M., and Burrows, J. P.: The ozone hole break-up in September 2002 as seen by SCIAMACHY on ENVISAT., J. Atmos. Sci., 62, 721-734, 2005 b.

Wagner, T., Wittrock, F., Richter, A., Wenig, M., Burrows, J. P., and Platt, U.: Continuous monitoring of the high and persistent chlorine activation during the Arctic winter 1999/2000 by the GOME instrument on ERS-2, J. Geophys. Res., 107, 8267, doi:10.1029/2001JD000466, 2002.

Weber, M., Eichmann, K.-U., Wittrock, F., Bramstedt, K., Hild, L., Richter, A., Burrows, J., and Müller, R.: The cold Arctic winter 1995/96 as observed by GOME and HALOE: Tropospheric wave activity and chemical ozone loss, Q. J. R. Meteorol. Soc., 128, 1293-1319, 2002.

Weber, M., Lamsal, L. N., Coldewey-Egbers, M., Bramstedt, K., and Burrows, J. P.: Pole-to-pole validation of GOME WFDOAS total ozone with groundbased data, Atmos. Chem. Phys., 5, 1341-1355, doi:10.5194/acp-5-1341-2005, 2005. 
Weber, M., Lamsal, L. N., and Burrows, J. P.: Improved SCIAMACHY WFDOAS total ozone retrieval: Steps towards homogenising long-term total ozone datasets from GOME, SCIAMACHY, and GOME2, Proc. "Envisat Symposium 2007", Montreux, Switzerland, 23-27 April 2007, ESA SP-636, July 2007, available at: http://envisat.esa.int/envisatsymposium/ proceedings/posters/3P4/463281we.pdf, 2007.

Weber, M., Dikty, S., Burrows, J. P., Garny, H., Dameris, M., Kubin, A., Abalichin, J., and Langematz, U.: The Brewer-Dobson circulation and total ozone from seasonal to decadal time scales, Atmos. Chem. Phys., 11, 11221-11235, doi:10.5194/acpd-111011-2011, 2011.

Winkler, H., Sinnhuber, M., Notholt, J., Kallenrode, M.-B., Steinhilber, F., Vogt, J., Zieger, B., Glassmeier, K.-H., and Stadelmann, A.: Modeling impacts of geomagnetic field variations on middle atmospheric ozone responses to solar proton events on long timescales, J. Geophys. Res., 113, D02302, doi:10.1029/2007JD008574, 2008.
WMO: Scientific Assessment of Ozone Depletion: 2011, World Meteorological Organization, Global Ozone Research and Monitoring Project, Report No. 52, Geneva, Switzerland, 2011.

Wohltmann, I., Wegner, T., Müller, R., Lehmann, R., Rex, M., Manney, G. L., Santee, M. L., Bernath, P., Sumińska-Ebersoldt, O., Stroh, F., von Hobe, M., Volk, C. M., Hösen, E., Ravegnani, F., Ulanovsky, A., and Yushkov, V.: Uncertainties in modelling heterogeneous chemistry and Arctic ozone depletion in the winter 2009/2010, Atmos. Chem. Phys., 13, 3909-3929, doi:10.5194/acp-13-3909-2013, 2013. 


\section{Appendix A}

Table A1. Abbreviations.

\begin{tabular}{|c|c|}
\hline ATLAS & Alfred Wegener Institute Lagrangian Chemistry/Transport Model \\
\hline BASCOE & Belgian Assimilation System for Chemical ObsErvations \\
\hline CTM & Chemistry Transport Model \\
\hline CALIOP & Cloud-Aerosol Lidar with Orthogonal Polarisation \\
\hline DOAS & Differential Optical Absorption Spectroscopy \\
\hline GOME & Global Ozone Monitoring Experiment \\
\hline GSG & GOME/SCIAMACHY/GOME-2 \\
\hline ECMWF & European Centre for Medium Range Weather Forecasts \\
\hline ERA & ECMWF Re-Analysis \\
\hline ERS-2 & European Remote Sensing Satellite \\
\hline ESA & European Space Agency \\
\hline EUMETSAT & European Organisation for the Exploitation of Meteorological Satellites \\
\hline FTIR & Fourier Transform Infrared Spectroscopy \\
\hline IUP & Institut für Umweltphysik \\
\hline LINOZ & Linearized Ozone \\
\hline LT & Local Time \\
\hline MetOp-A & Meteorological Operational Satellite \\
\hline MIDRAD & Middle Atmosphere Radiation \\
\hline MIPAS & Michelson Interferometer for Passive Atmospheric Sounding \\
\hline MLS & Microwave Limb Sounder \\
\hline NDACC & Network for the Detection of Atmospheric Composition Change \\
\hline $\mathrm{NH}$ & Northern Hemisphere \\
\hline OMI & Ozone Monitoring Instrument \\
\hline $\mathrm{OMH}$ & Ozone Mini-Hole \\
\hline OSIRIS & Optical Spectrograph and InfraRed Imager System \\
\hline PSC & Polar Stratospheric Cloud \\
\hline PV & Potential Vorticity \\
\hline SCIAMACHY & Scanning Imaging Absorption SpectroMeter for Atmospheric CHartography \\
\hline SH & Southern Hemisphere \\
\hline SMR & Sub-millimeter Microwave Radiometer \\
\hline SZA & Solar Zenith Angle \\
\hline TOMS & Total Ozone Mapping Spectrometer \\
\hline UARS & Upper Atmosphere Research Satellite \\
\hline UKMO & United Kingdom Met Office \\
\hline UV & Ultraviolet \\
\hline WMO & World Meteorological Organisation \\
\hline
\end{tabular}

